DANMARKS GEOLOGISKE UNDERSØGELSE · DGU SERIE A · NR. 23 MILJØMINISTERIET · Geological Survey of Denmark · DGU SERIES A · NO. 23

\title{
Upper Triassic-Lower Jurassic tidal deposits of the Gassum Formation on Sjælland, Denmark
}

BY:

LARS HENRIK NIELSEN, FLEMMING LARSEN AND NILS FRANDSEN

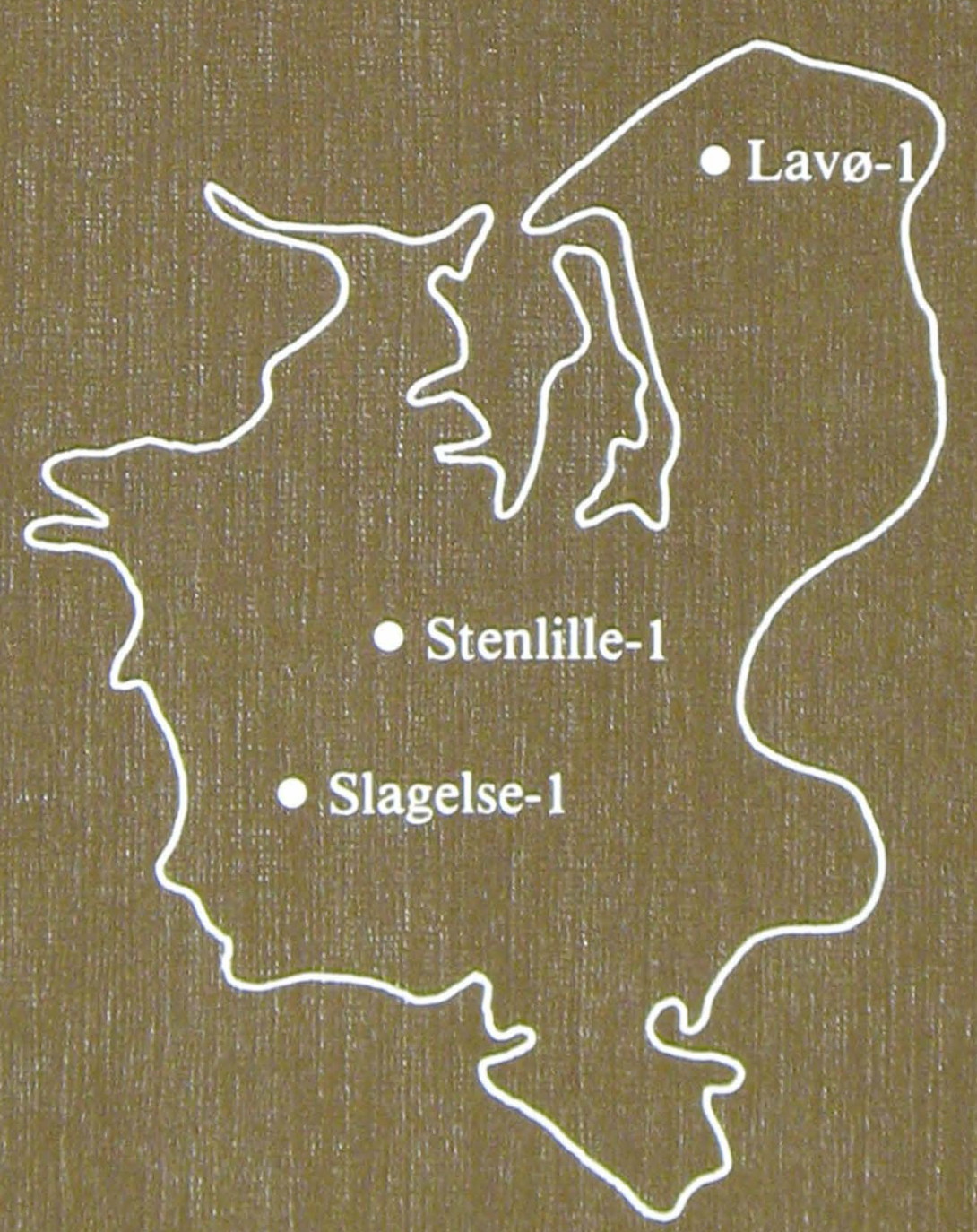




\section{Upper Triassic-Lower Jurassic tidal deposits of the Gassum Formation on Sjælland, Denmark}

BY

LARS HENRIK NIELSEN, FLEMMING LARSEN AND NILS FRANDSEN 


\section{Key words:}

Danish Subbasin, Sjælland,

Upper Triassic - Lower Jurassic,

depositional environment.

\section{Vignet:}

Sjælland with the three investigated wells.

DGU Serie A nr. 23.

ISBN 87-88640-42-6

ISSN 0901-0270

Oplag: 1000

Tryk: AiO Tryk as, Odense

Tegning: Eva Melskens and Inge Martin-Legéne.

Dato: 16.10 .1989

Lars Henrik Nielsen; DGU, Thoravej 8, DK-2400 Copenhagen NV.

Flemming Larsen; Rambøll \& Hannemann, sektor Tage Sørensen, Blokken 44, DK-3460 Birkerød.

Nils Frandsen; DOPAS, Slotsmarken 16, DK-2970 Hørsholm.

Redaktion: Leif Banke Rasmussen

(C) Danmarks Geologiske Undersøgelse

Thoravej 8, DK-2400 København NV

I kommission hos: Geografforlaget ApS.

Ekspedition: Fruerhøjvej 43, 5464 Brenderup

Telefon: 64441683 


\section{Contents}

\begin{abstract}
$\ldots \ldots \ldots \ldots \ldots \ldots \ldots \ldots \ldots \ldots, 4$
Introduction ...................... 5

Geological setting and age $\ldots \ldots \ldots \ldots \ldots \ldots, 6$

Facies descriptions and interpretations ......... 11

Facies 1 - Large-scale cross-bedded sandstone . 12

Facies 2 - Large-scale, low-angle cross-bedded sandstone $\ldots \ldots \ldots \ldots \ldots \ldots \ldots, 12$

Facies 3 - Inclined heterolith ............ 15

Facies 4 - Small-scale cross- to parallel laminated sandstone and mudstone . 15

Facies 5 - Heterolith ................ 17

Facies 6 - Small-scale cross- and parallel laminated siltstone
\end{abstract}

Facies 7 - Parallel laminated claystone ....., 20

Facies 8 - Coal ...................... 21

Vertical succession of facies in the cored intervals 22

Stenlille-1 ....................... 22

Lav $\emptyset-1 \ldots \ldots \ldots \ldots \ldots \ldots \ldots \ldots . \ldots \ldots$

Description and interpretation of the uncored parts of the formation ................. 25

Stenlille-1 ........................ 25

Lavø-1........................ 25

Slagelse-1 ...................... 25

Depositional model and palaeogeography ...... 27

Acknowledgements.................... 28

References .......................... 29 


\section{Abstract}

Three deep wells on the Danish island of Sjalland penetrate the Upper Triassic - Lower Jurassic Gassum Formation. The formation has been the subject of a facies analysis of cored sediments and interpretation of petrophysical logs. The principal part of the work presented is based on data from the Stenlille-1 well. The sediments were deposited in a NW-SE trending, microto mesotidal, prograding coastal zone and the adjacent fluvial hinterland. In the Stenlille-1 well, the coastal progradation is recorded as a thick, coarse-grained sandstone unit deposited within a barrier island complex. This basal part of the formation is overlain by four stacked regressive sequences consisting of finegrained sandstones and mudstones deposited on tidal flats. A thin transgressive sandstone sheet terminates the formation and marks the boundary to marine claystones of the Fjerritslev Formation. 


\section{Introduction}

The purpose of this paper is to present an interpretation of the depositional environment of the Upper Triassic - Lower Jurassic Gassum Formation carried out on material from the wells Stenlille-1, Slagelse-1, and Lav $\emptyset-1$ in the southeastern part of the Danish Subbasin (fig. 1). The two latter wells were drilled by Danish American Prospecting Company, D.A.P.Co., in 1959. The Stenlille-1 well was drilled in 1980 by Dansk Olie og Naturgas A/S, and about $60 \mathrm{~m}$ were cored continuously from the top of the formation. Pe- trophysical logs were run in the whole formation which is about $150 \mathrm{~m}$ thick in this area. Interpretations of depositional environment are based on a facies analysis of the cored intervals. The interpretations are extended to the whole formation by studying petrophysical log motifs, cuttings samples and sidewall cores, and an interpretation of the depositional environment and the palaeogeography of the formation on Sjælland is proposed.

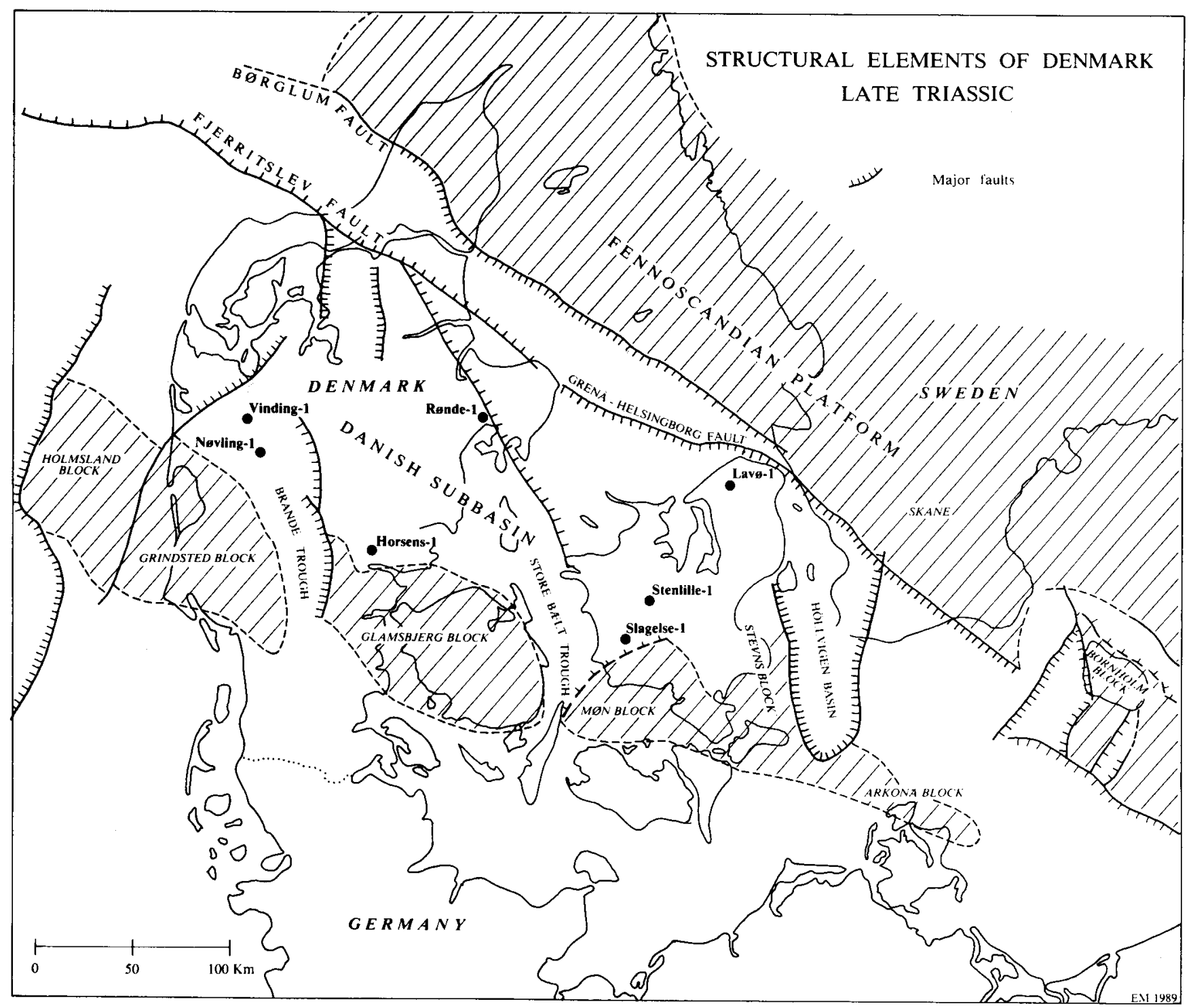

Fig. 1. Structural elements of Denmark in the Late Triassic. The three studied wells on Sjalland are placed on a line perpendicular to the boundary between the Fennoscandian Platform and the Danish Subbasin. Modified after unpublished structural map by J.C. Baartmann (1975). 


\section{Geological setting and age}

The Gassum Formation is found in wells north of the Ringk øbing-Fyn High and extends to the northwest out into the North Sea area. It is uncertain how far the formation extends towards the east and southeast. Within the Danish Subbasin the thickness of the formation exceeds $200 \mathrm{~m}$ in a relatively small depocentre situated in northern Jylland between the Fjerritslev and Børglum Faults (fig.1) and a larger depocentre situated in North Sjælland and the southern part of Kattegat, south of the Grenå-Helsingborg Fault (Bertelsen 1978).

The age of the Gassum Formation was established by Sorgenfrei and Buch (1964) and Michelsen (1975). The lower boundary is of Early Rhaetian age and the upper boundary is diachronous, ranging from Late Rhaetian to Sinemurian/Pliensbachian(?). Early Sinemurian ages of the formation are found in the northeastern part of the basin (Michelsen, 1975) and reflect onlap towards the northeast probably due to the Early Jurassic eustatic rise in sea-level.

In the central parts of the Danish Subbasin the Gassum Formation overlies the brackish to marine Vinding Formation of Late Norian age. In the more marginal parts of the subbasin the formation overlies the fluviatile Skagerrak Formation of Scythian to Early Rhaetian age (Bertelsen 1978, 1980).

The depositional environment of the Gassum Formation has been interpreted as deltaic by Larsen (1966). Bertelsen (1978) subdivided the formation into three members. The lower G-1 Member is an upwards coarsening unit of claystone, siltstone, and sandstone, locally with coal seams, constituting the Gassum Delta of Larsen (1966). The overlying G-2 Member is characterized by the dominance of claystone with minor siltstone and fine-grained sandstone, interpreted by Bertelsen (1978) as a drowning delta-plain. The G-3 Member grades from silty claystone into fine-grained sandstone and siltstone. It is interpreted as a regressive event $-\mathrm{a}$ final pulse in the Early Cimmerian tectonic phase, during which limnic conditions returned to the basin (Bertelsen 1978, p. 16-17).

Bertelsen (1978) correlated the G-1, G-2, and G-3 Members to the deltaic and limnic Vallåkra, Mine and Helsingborg Beds in Skåne, now named Vallåkra, Bjuv, and Helsingborg Members respectively (Sivhed 1984).

The shift from the brackish-marine mudstones of the Vinding Formation to the shallow marine sandstones of the Gassum Formation may have been tectonically con- trolled (Bertelsen 1978). Fault activity in the Fennoscandian Border Zone during the Late Triassic has been documented by several authors (Troedsson 1932; Gry 1969; Gravesen et al. 1982; Pegrum 1984; Vejbæk 1985; Norling and Bergström 1987), and the increase of coarse-clastic material in the Danish Subbasin during the Rhaetian could reflect increasing erosion in the area as a result of faulting and uplift. Alternatively, it may be attributed to the regional Northwest European eustatic fall in sea-level during Rhaetian time suggested by Hallam $(1981,1984)$ and Vail and Todd (1981).

The Gassum Formation is overlapped by the muddy Fjerritslev Formation, interpreted as a marine shelf deposit (Michelsen 1975, 1978; Pedersen 1983, 1985). The change from shallow marine sand to shelf mud probably reflect a eustatic rise in sea-level in the Early Jurassic (Michelsen, 1975, 1978; Bertelsen, 1978; Pedersen, 1983; Hallam 1981, 1984).

In the Stenlille-1 well the Gassum Formation is $144 \mathrm{~m}$ thick (1507.10-1651.00 m, all depths are below Kelly Bushing) and overlies the Vinding Formation (fig.2). Michelsen (1980) identified an ostracod fauna dominated by Emphasia ssp. just below the boundary indicating an Norian-Early Rhaetian age for the upper part of the Vinding Formation. Hansen (1981) found a Late Rhaetian palynomorph assemblage just above the Gassum Formation - Fjerritslev Formation boundary. These biostratigraphical data indicate a Rhaetian age for the Gassum Formation in the Stenlille-1 well.

In the Slagelse- 1 well the Gassum Formation is $116 \mathrm{~m}$ thick (1171-1287 m) and overlies the Vinding Formation (fig. 2). Bertelsen $(1978,1980)$ defined the upper boundary at $1150 \mathrm{~m}$ but log correlation to Stenlille-1 suggests that the boundary should be moved downhole to $1171 \mathrm{~m}$ (Michelsen 1980).

The interval 1169-1332 $\mathrm{m}$ was suggested to be of Rhaetian age by Larsen and Buch (1960). Ostracod faunas indicate a Hettangian - Lower Sinemurian age for the overlying interval 1012-1169 m (Michelsen 1975). Hence the biostratigraphical data suggest a Rhaetian age for the formation in the Slagelse- 1 well.

In the Lav $\emptyset$ - 1 well the Gassum Formation was penetrated in the interval $2133-2368 \mathrm{~m}$ (fig. 2) giving a thickness of $235 \mathrm{~m}$ (Bertelsen 1978, 1980). Buch (in Dinesen 1960) suggested that the interval 2134-2368 m 


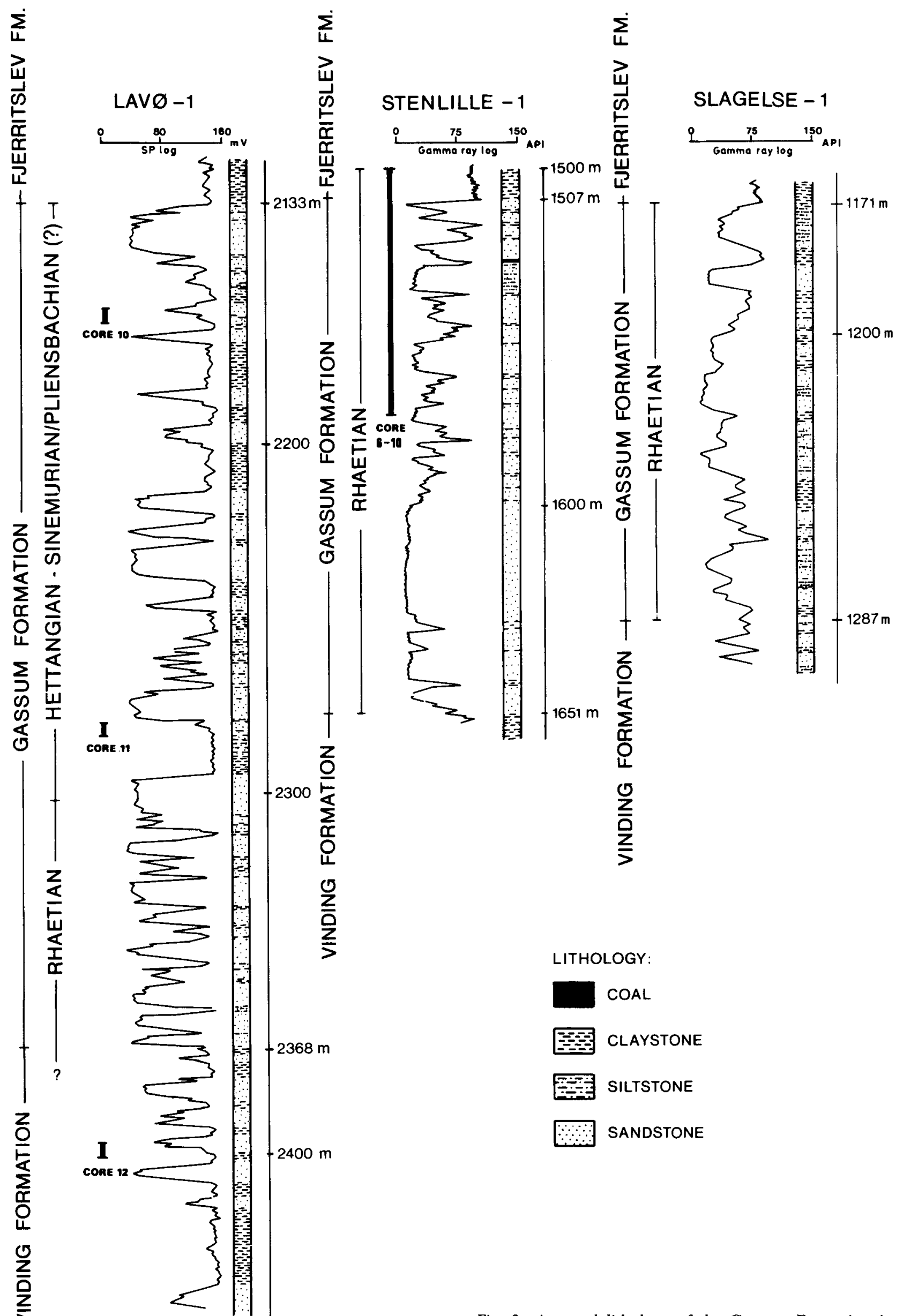

Fig. 2. Age and lithology of the Gassum Formation in the studied wells on Sjalland. Cored intervals are indicated. 


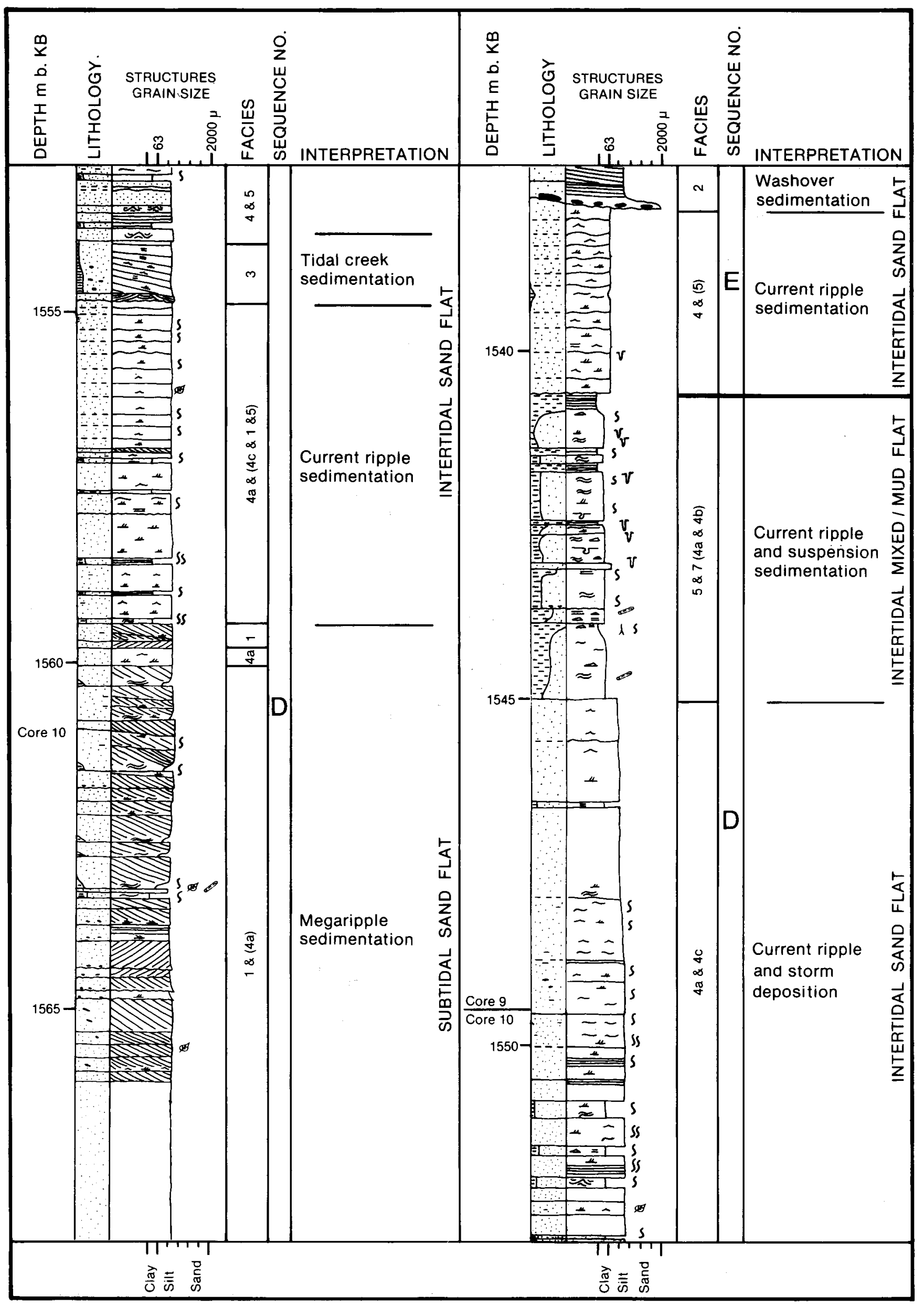

Fig. 3. Sedimentological log and interpretation of cored sediments from the Gassum Formation in Stenlille-1. 


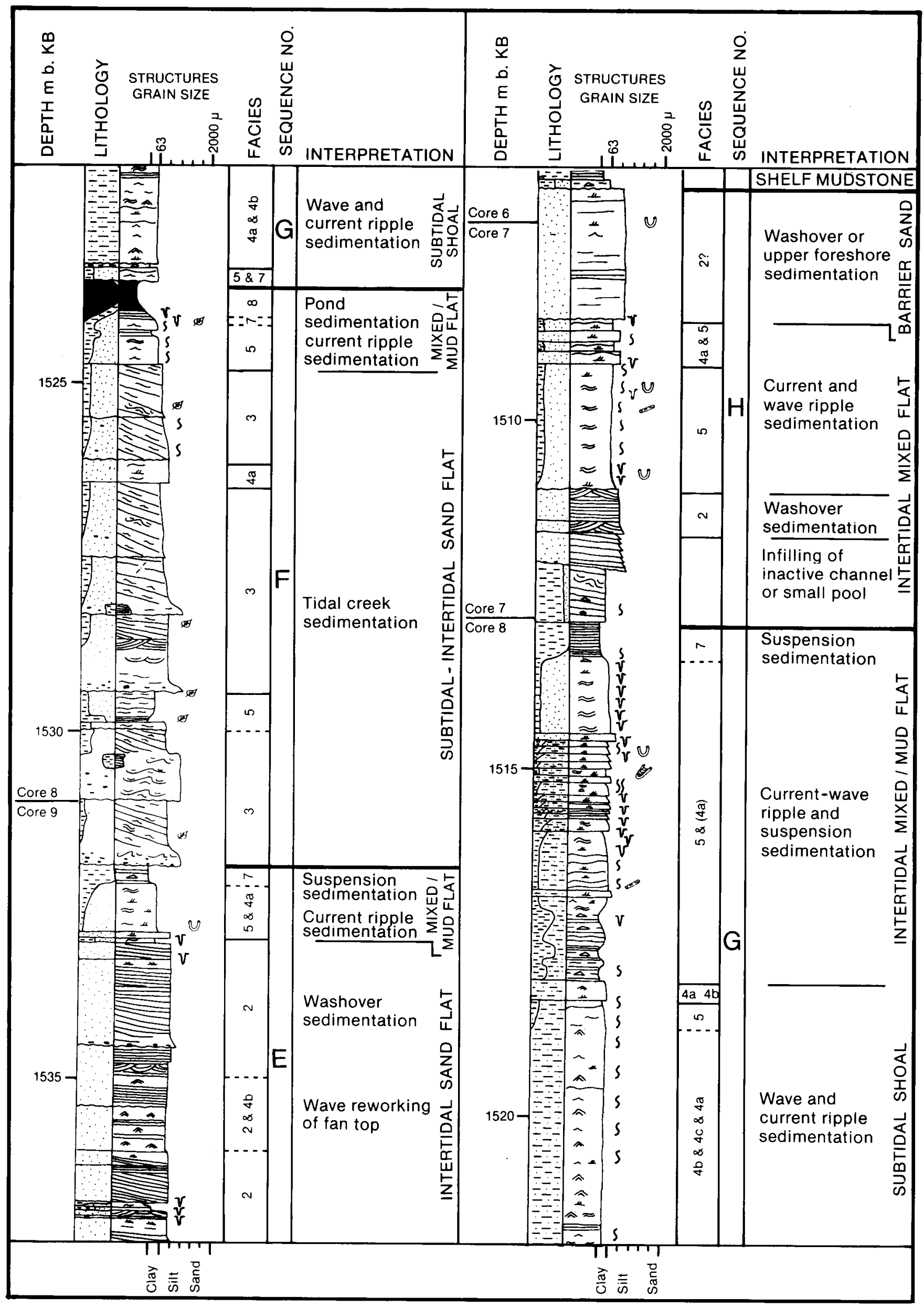


is of Rhaetian or Liassic age. The ostracod fauna indicates the presence of the Lower Jurassic O.danica, C.betzi-C.crassireticulata Zones at least down to 2304 m (Michelsen 1975). Dinocysts and the ostracods Emphasia spp. from core 12 (2395-2400 m) suggest an Early Rhaetian or possibly Late Norian age (Poulsen 1985 and Michelsen pers. comm. 1987).

The sparse biostratigraphical data thus indicates that the interval referred to the Gassum Formation by Bertelsen (1978), is of Rhaetian to Sinemurian/ Early Pliensbachian (?) age.

According to Bertelsen $(1978,1980)$ the formation overlies the Skagerrak Formation but the sediments of core 12 are not typically of the Skagerrak Formation as they are dominated by partly bioturbated, olive grey, brownish and in places greenish and reddish claystones and siltstones with glauconite. The glauconite, the bioturbation and the above mentioned find of dinocysts and the ostracods Emphasia spp. suggest a marine to brackish environment. Emphasia spp. are known from the Vinding Formation and the lower part of the Gassum Formation (Christensen 1971, 1973), and this may suggest that it is the Vinding Formation which underlies the Gassum Formation in Lavø-1 as in Slagelse-1 and Stenlille-1. 


\section{Facies descriptions and interpretations}

The total recovered length of the continuous cores from the Gassum Formation in the Stenlille-1 well is $61.7 \mathrm{~m}$ (1506.7 m-1568.4 m, cores 6-10, rec. $100 \%$ ) (fig.3). The lengths of the cores in the Lavø-1 well are $2.64 \mathrm{~m}(2163 \mathrm{~m}-2166 \mathrm{~m}$, core 10 , rec. $88 \%)$, and $5.5 \mathrm{~m}$ (2277.5 m - $2283 \mathrm{~m}$, core 11, rec. 100\%) (fig.4). In
Slagelse-1 no cores were taken in the Gassum Formation.

The cored sediments have been divided into eight sedimentary facies which are described and interpreted below.

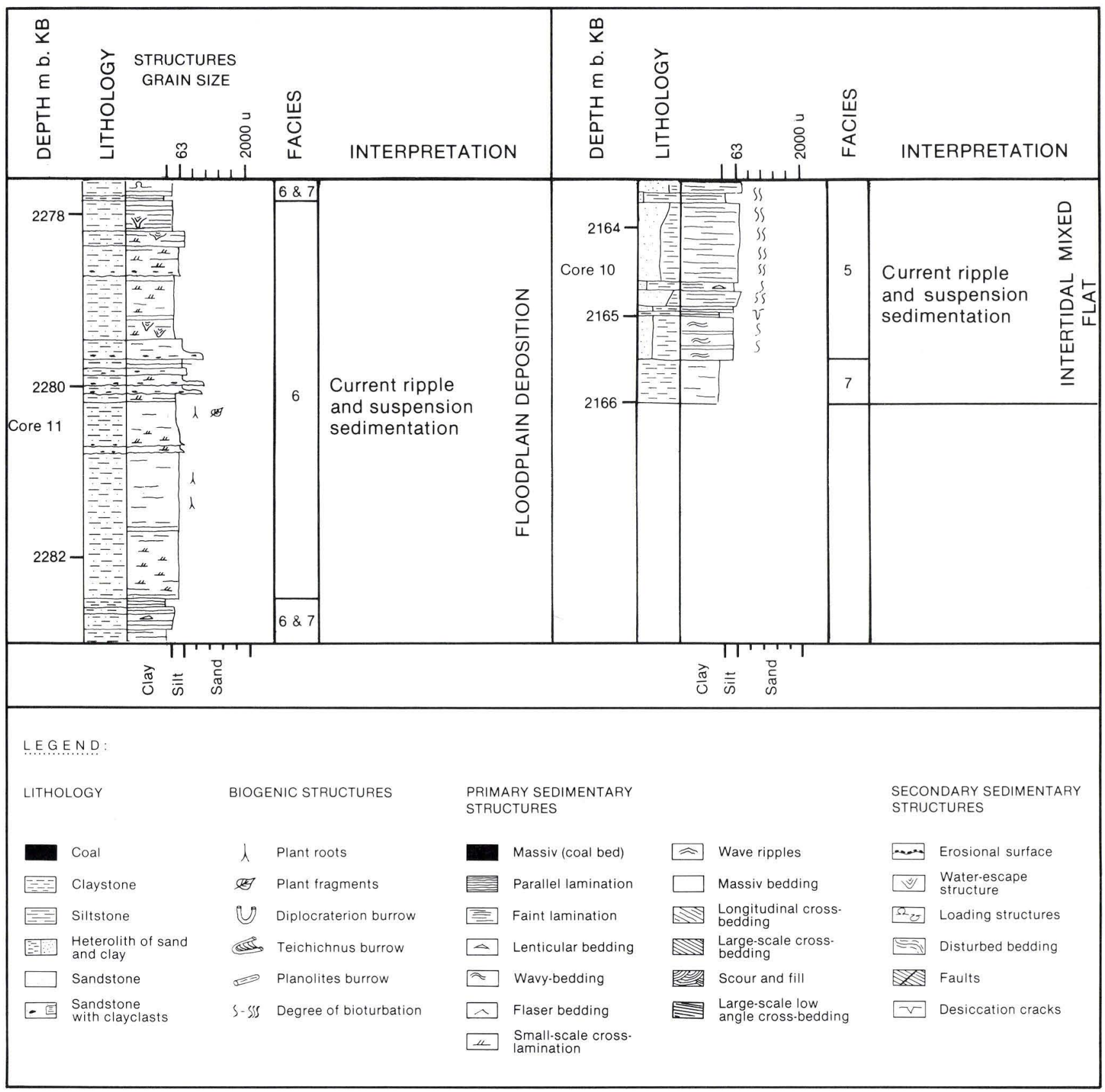

Fig. 4. Sedimentological $\log$ and interpretation of the coredsediments from the Gassum Formation in Lav $\varnothing-1$. 


\section{Facies 1 - Large-scale cross-bedded sandstone}

Description: This facies consists of well sorted, light grey, fine- to medium-grained sandstone with abundant clasts of mudstone.

It is large-scale cross-bedded (fig. 5) in sets up to 40 $\mathrm{cm}$ thick. Foresets dip up to $20^{\circ}$. Occasionally the foresets are draped by $1-3 \mathrm{~mm}$ thick clay- and mudstone laminae or cut by gently dipping planes with small ripples (fig. 6).

The foresets show angular contact or tangential bottomsets consisting of cross-laminated sandstone lenses, enclosed by mudstone laminae (fig. 6). Opposed dip directions of foreset laminae are seen in superjacent lenses separated by mudstone laminae.

Planolites burrows are present in the mudstone laminae.

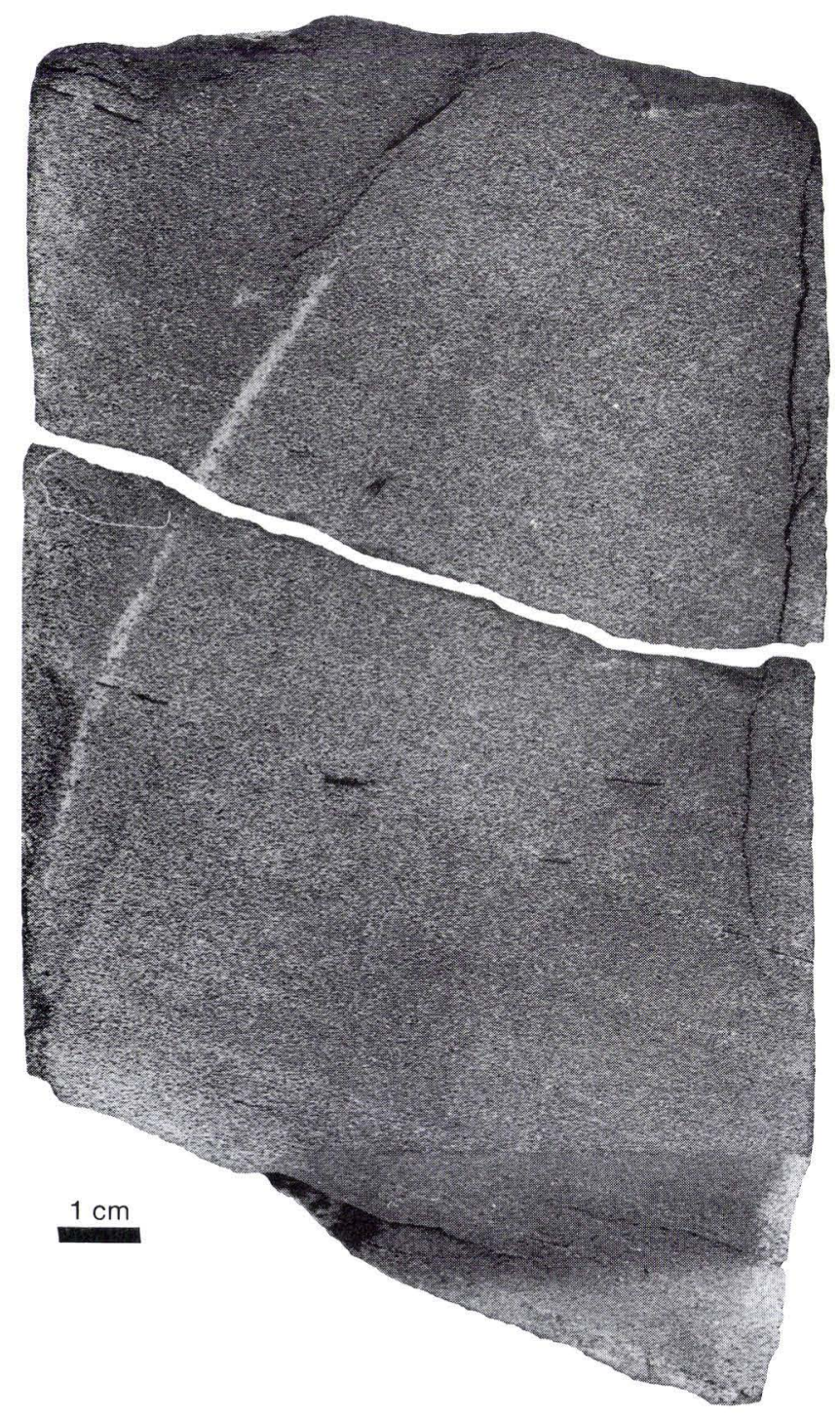

Fig. 5. Facies 1, large-scale cross-bedded sandstone formed by subtidal megaripples. Small mudstone clasts accentuate the cross-bedding, Stenlille-1, $1564.4 \mathrm{~m}$.
Facies 1 makes up $10 \%$ of the cored interval in the Stenlille- 1 well, but is not present in the Lav $\varnothing-1$ cores .

Interpretation: The cross-bedding was formed by leeside avalanching of migrating megaripples and the mudstone drapes are interpreted as records of single slackwater events (Terwindt and Breusers 1972, 1982). The ripples migrating up the lee-sides and the diverging directions of ripple foreset dips in bottomsets, indicate that bidirectional currents characterized the environment. Back-flow ripples can be excluded due to the presence of the enclosing mudstone laminae.

The evidence of a bidirectional flow system with varying flow velocities (fig. 6) strongly points to a tidal environment. Ripples enclosed by couplets of mudstone laminae are diagnostic features of subtidal environments (Visser 1980).

\section{Facies 2 - Large-scale, low-angle cross- bedded sandstone}

Description: This facies consists mainly of grey, well to moderately sorted, fine- to very fine-grained sandstone with a relatively high content of mafic and opaque minerals in distinct laminae.

It is characterized by up to $1 \mathrm{~m}$ thick sets of largescale, low-angle cross-bedding and slightly dipping parallel laminae (fig. 7). The foresets dip from $3^{\circ}$ to $15^{\circ}$ and are often curved (fig. 8A). Tangential bottomsets grade upward into steeper foresets, which again grade into concordant or slightly discordant topsets, giving the impression of sigmoidal foresets.

These sandstones are underlain by erosion surfaces. Mudstone clasts up to $7 \mathrm{~cm}$ across rest on the erosion surfaces (fig. 8B). The cross-bedded sandstones are overlain by thin layers of fine-grained sandstone with ripples and parallel lamination and are often capped by thin mudstone layers showing small, V-shaped, sand filled mudcracks arranged in polygonal patterns.

Diplocraterion burrows are seen in top of these sandstones, (fig. 8C) and Planolites burrows are seen in the mudstones.

Facies 2 represents $8 \%$ of the cored interval in the Stenlille-1 well, but it is not present in the Lavø-1 well.

Interpretation: The trace fossils in this facies suggest that the sandstones were deposited in a shallow marine environment (Seilacher 1967; Ekdale et al. 1984).

The occurrence of scours and large mudstone clasts at lower set boundaries suggest deposition during episodes of high energy. The low angle of inclination of foreset laminae suggests that avalanching and larger leeside eddies were not operating during the sedimentation. The sigmoidal foreset laminae suggest high flow velocities relative to grain sizes coupled with a high rate of grains falling out from suspension (Jopling 1965). This suggest that the cross-bedded sandstone was de- 


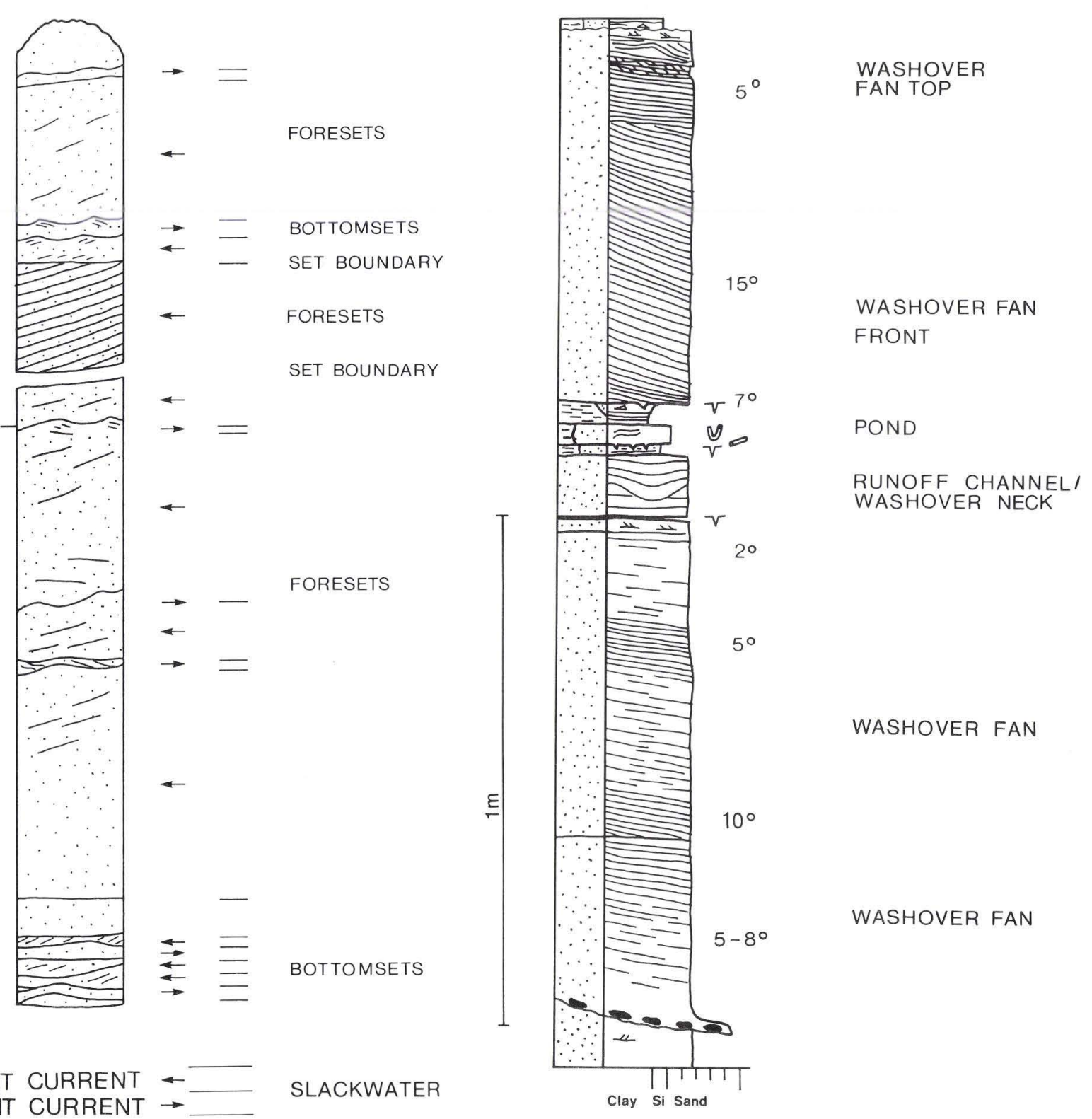

\section{DOMINANT CURRENT SUBORDINANT CURRENT $\rightarrow$}

Fig. 6. Facies 1. Two or three sets of large-scale cross-bedded sandstone formed by subtidal megaripples. Lenses of crosslaminated sandstone enclosed by laminae of mudstone are present in the bottomsets and within the foresets. The mudstone laminae were deposited during single slackwater events. The gently dipping planes draped by mudstone laminae are reactivation surfaces formed by subordinate currents and subsequent slackwater.

posited by sheet flows on the leeside of migrating bedforms or micro-deltas.

The gently dipping parallel laminae overlying the foresets are interpreted as topsets deposited under upper flow regime conditions. Sometimes the parallel lamination alternates with small-scale cross-lamination (fig. 8D). This indicates shifts in the bed configuration from upper-stage plane beds to fast moving ripples climbing at very low angles which suggests that the flow velocity fluctuated on top of the larger bedforms (Harms et al. 1982). Evidence of high flow velocities and very shallow depths is present as antidune struc-
Fig. 7. Facies 2, coalescing washover fans, Stenlille-1 (1538.0$1535.9 \mathrm{~m})$.

tures (fig. 8D) very similar to antidunes described from small ancient and recent washover fans (Barwis and Hayes 1985). The observed alternation between laminae rich in heavy minerals and rich in quartz is evidence of good primary textural segregation as known from recent washover fans (Schwartz 1982).

The mudstone layers on top of some of the sandstone beds were deposited after the vigorous episodes. The polygonal, V-shaped mudcracks interpreted as desiccation cracks, show that some of the bedforms became emergent.

The close similarity to structures observed in recent washover fans (e.g. Schwartz 1982, Barwis and Hayes 1985) and the evidence of sheet flow conditions and fluctuating shallow flows suggest that facies 2 represents washover fan deposits. 


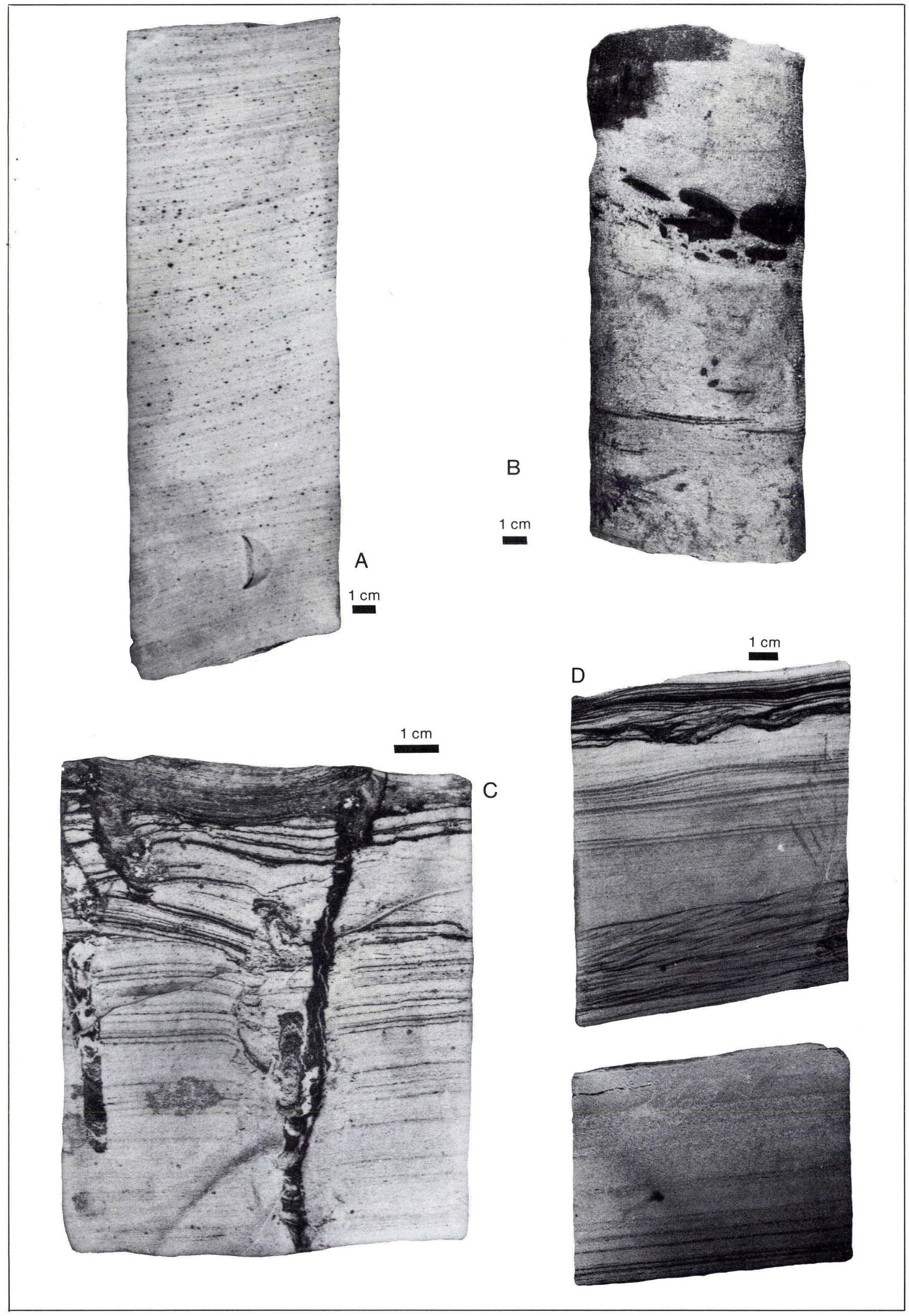


Fig. 8. Facies 2, washover fan, Stenlille-1.

A: Low-angle, curved foresets of sandstone deposited on the leeside of a washover fan. The dark spots are iron oxides and iron hydroxides precipitated due to dissolution of the mafic minerals in the sandstone after the core was taken $(1536.5 \mathrm{~m})$.

B: Erosion surface overlain by mudstone clasts and faintly laminated sandstone possibly representing a washower neck $(1538.0 \mathrm{~m})$.

$C$ : Diplocraterion burrows into top of washover fan deposits (1532.9 m).

D: Parallel lamination and slightly climbing ripple cross-lamination in topset beds indicating fluctuations of flow regime. In the upper part an antidune structure is seen indicating shallow water depth and high flow velocity during deposition $(1536.2 \mathrm{~m})$.

\section{Facies 3 - Inclined heterolith}

Description: This facies is composed of sandstones and mudstone-sandstone heteroliths. The sandstones are light grey, moderately sorted, and medium- to finegrained. The heteroliths consist of light grey, moderately sorted, fine- to very fine-grained sandstones and black mudstones. The mudstones are rich in plant fragments.

The facies is a rather complex succession of lithologies and sedimentary structures (fig. 9). Eight such successions, 0.6-1.1 m thick, are present in the cored interval of the Stenlille-1 well. Facies 3 always begins with an erosional surface, in most cases overlain by sandstones, which grade into inclined heteroliths (fig. 9A). In successions without a basal sandstone, inclined heteroliths dominate.

In the basal sandstones massive bedding and faint crossbedding is seen occasionally, but disturbed bedding is widespread. The sandstones contain angular intraformational clasts, ranging in size from a few $\mathrm{mm}$ to several $\mathrm{cm}$ (fig. 9B). Often the lithology of these clasts is the same as that of the inclined heteroliths above, but mudstone clasts are also present. The amount and size of the clasts generally decreases upward in facies 3 .

The layers in the inclined heteroliths dip from $5^{\circ}$ to $20^{\circ}$, and an upwards decreasing dip is generally seen. Flaser bedding, wavy bedding, and irregular parallel bedding are seen in the heteroliths (figs 9A and 9C). Interbeds of massive or cross-laminated sandstones and slightly bioturbated, up to $1 \mathrm{~cm}$ thick mudstone layers constitute a minor part of the heteroliths.

Faults and disturbed bedding are common in the heteroliths (fig. 9D).

Gently dipping, medium- to fine-grained, laminated sandstone layers, $10-20 \mathrm{~cm}$ in thickness, occasionally overlie the inclined heteroliths.

Facies 3 makes up $12 \%$ of the cored interval in the Stenlille-1 well, but is not present in the cores from the Lavø-1 well.
Interpretation: The erosional lower boundaries and the occurrence of abundant intraformational clasts suggest that the sediments in facies 3 were deposited by channelized flows.

The sandstones on the channel floors were deposited by megaripple migration, and the massive sandstones may represent phases of very rapid deposition. The large, angular, heterolithic clasts which sometimes are present in the sandstones (fig. 9B) were probably not transported far, as it is likely they would have disintegrated quickly during prolonged transport. Thus, these clasts probably slumped into the thalweg due to undercutting of channel banks. Similar channel lags are described from ancient tidal deposits by Sellwood (1972, 1975) and Carter (1975).

The inclined heteroliths overlying the basal sandstones deviate from avalanche-type foresets formed by migration of transverse bedforms. The very frequent alternation in grainsize shows that deposition resulted from relatively strong currents regularly alternating with weak currents and periods of slackwater. This frequent shift in flow velocities during sedimentation of channel deposits is suggestive of a tidal setting.

Inclined heteroliths formed by lateral accretion have been reported from point bars in ancient and recent tidal channels (van Straaten 1954; Reineck 1958, 1967; Bridges and Leeder 1976; Reineck and Singh 1980; de Mowbray 1983; Zaitlin and Dalrymple 1985; Smith 1985, 1988). By analogy the inclined heteroliths are thus interpreted as having been deposited on point bars in tidal channels and are termed longitudinal crossbedding (sensu Reineck 1958).

The upward decreasing dips of the inclined heterolithic layers and the gradual transition to subhorizontal layers reflect the passage of a laterally migrating point bar with a curved accretion surface; the inclined layers represent bar front progradation and the subhorizontal layers represent bar top aggradation.

The faulting in the inclined heteroliths and the relatively limited bioturbation in the sediments, compared to the adjacent facies are in agreement with observations from recent longitudinal cross-bedding (Reineck and Singh 1980).

\section{Facies 4 - Small-scale cross- to parallel laminated sandstone and mudstone}

Three subfacies are defined on the basis of the various sedimentary structures. The lithology of all three subfacies is moderately to well sorted, light grey, finegrained sandstone and siltstone containing varying proportions of dark grey to black mudstone laminae with lignite fragments. Small concretions of pyrite are present. 

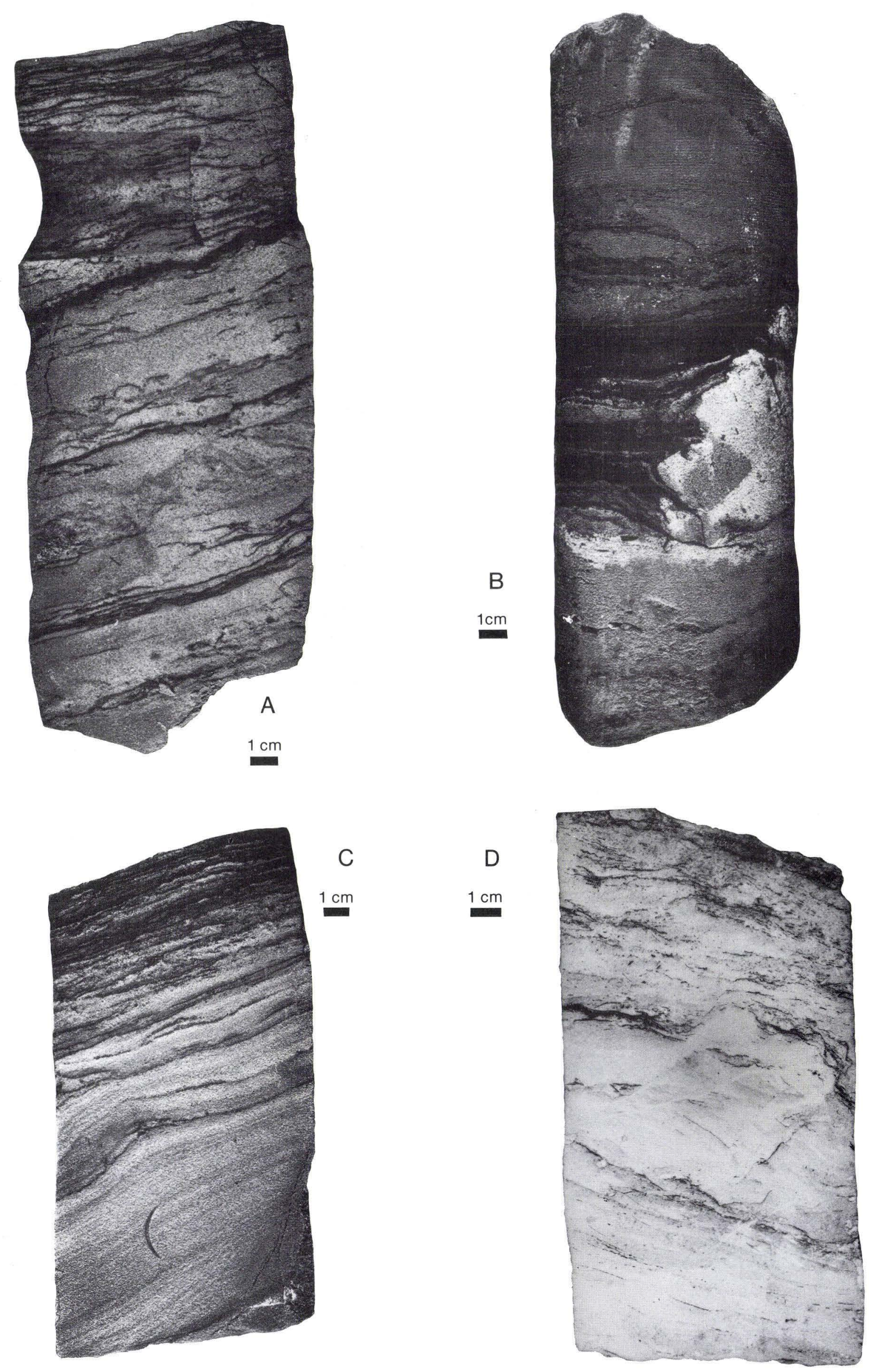
4ig. 9. Facies 3, longitudinal cross-bedding (inclined heteroliths) formed by point bar progradation, Stenlille-1.

A: Alternating sandstone and mudstone layers. The upwards gradually decreasing dip reflects the lateral migration of a concave upward accretion surface of a point bar (1554.5 $m$ ).

B: The basal sandy part of a channel fill with a large heterolithic and partly destroyed clast probably slumped into the channel thalweg from a cut bank. Several small claystone clasts are seen, too $(1538.2 \mathrm{~m})$.

C: Inclined heterolithic layers characterized by irregular parallel bedding. The bedding is disturbed in the lower sandy part $(1528.4 \mathrm{~m})$.

D: Small synsedimentary faults cutting the longitudinal crossbedding $(1527.6 \mathrm{~m})$

Bioturbation often occurs and Diplocraterion burrows are frequently seen.

In the Stenlille-1 well this facies, mainly developed as subfacies $4 \mathrm{a}$, constitutes $37 \%$ of the cored interval. In the cores from Lav $\varnothing-1$ the facies is not represented.

\section{Subfacies $4 a$}

Description: Trough cross-laminated sandstone with thin interbeds of parallel laminated sandstone and mudstone (fig. 10A) dominate this subfacies. Opposed directions of foreset dips are seen. Ripples are often draped with thin, continuous mudstone laminae. Single flaser bedding, bifurcating and wavy flaser bedding is seen (Reineck and Wunderlich 1968).

In sequences without mudstone laminae the well sorted sandstones appear massive. The massive structure may be a result of bioturbation which is clearly intensive in some horizons.

Interpretation: The cross-lamination was probably formed by non-oscillatory currents. Reversed foreset dips indicate changes in current directions.

The thin parallel laminated sandstone and mudstone interbeds are interpreted as suspension deposits. The thin mudstone laminae may be deposited during slackwater periods (Terwindt and Breusers 1972, 1982).

\section{Subfacies 4b}

Description: Incipient lenses, chevron structures and intricately interwoven cross-lamination (fig. 10B) (de Raaf et al. 1977), characterize this subfacies. Furthermore, interbeds of even to undulatory, parallel laminated sandstone and siltstone with erosional lower boundaries are present, together with thin continuous mudstone layers.

Interpretation: Subfacies $4 \mathrm{~b}$ was deposited under the influence of oscillatory water movements. The parallel laminated, erosively based sandstone and siltstone may have been deposited under sheet flow conditions due to strong wave-action from shoaling waves (Clifton et al. 1971; Clifton 1976; Davidson-Arnott and Greenwood 1976; de Raaf et al. 1977).

The presence of Diplocraterion burrows and the wave induced sedimentary structures, interrupted by continuous mudstone layers, indicate a shallow marine environment where periods of weak or no water movements alternated with periods of wave action.

\section{Subfacies $4 c$}

Description: This subfacies consists of $2-10 \mathrm{~cm}$ thick, graded sandstone beds with sharp or erosive lower boundaries. The basal portion of these sandstone beds is medium- to fine-grained, structureles and shows a normal grading (fig. 10C). Upwards the beds develop indistinct parallel lamination which passes up into a cross-laminated, thin interval with mud flasers overlain by a thin, draping mudstone layer.

Interpretation: The relatively coarse grain size, the lack of stratification and the absence of mud in the lower part of the sandstone beds indicates that the sand was deposited rapidly from heavily loaded turbulent suspensions. The upward fining trend and transition to parallel lamination and cross-lamination indicate gradually decreasing energy and supply of sand. The draping mudstone layers reflect further reduced energy.

This interpretation implies that subfacies $4 \mathrm{c}$ may represent deposition during waning storm events. Terwindt (1981) describes similar storm deposits from recent tidal sediments.

\section{Facies 5 - Heterolith}

Description: This facies consists of moderately sorted, light grey, fine-grained sandstone and black mudstone, rich in plant fragments. In some horizons the sandstone grades into siltstone.

The heteroliths are characterized by thinly parallel layered sandstone and mudstone, wavy bedding, lenticular bedding and single flaser bedding (figs. 11A and B) (Reineck and Wunderlich 1968; Reineck 1972).

Small upwards fining sequences, few $\mathrm{mm}$ to some $\mathrm{cm}$ thick, are seen in the heteroliths (fig. 11C). These sequences often begin with an erosional surface overlain by cross-laminated and/or parallel laminated, finegrained sandstone or siltstone grading upward into very thinly laminated mudstone. The mud content increases upwards, and the sequences are often terminated by mudstone laminae with thicknesses up to $20-30 \mathrm{~mm}$.

$\mathrm{V}$-shaped, sand filled mudcracks arranged in polygonal patterns are seen on clayey bedding planes (fig. 11D). Plant roots penetrate parts of the heteroliths (fig. $11 \mathrm{E})$. 


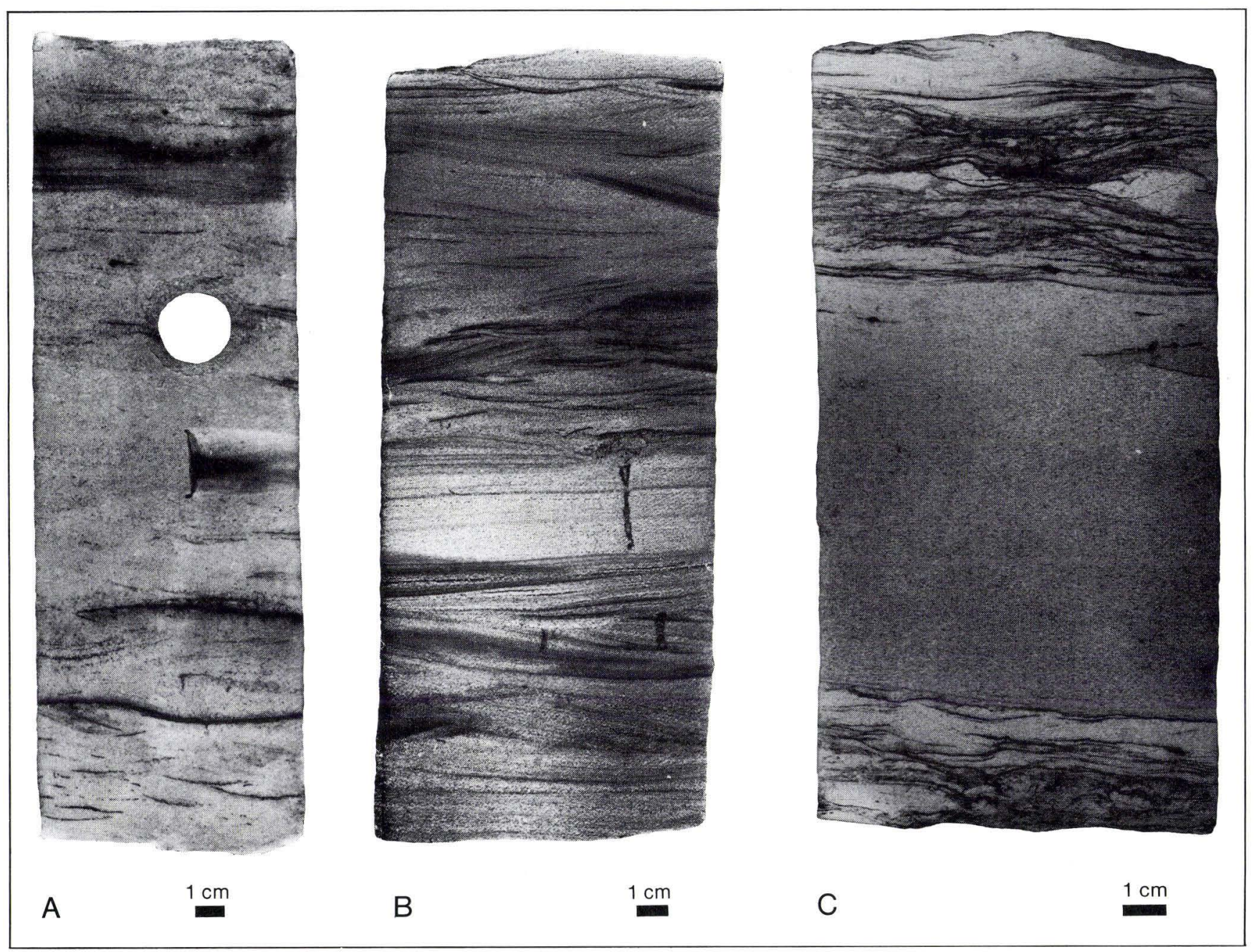

Fig. 10. Facies 4, Stenlille-1.

A: Small-scale cross-laminated sandstone with flaser bedding and a few continuous claystone laminae generated by tidal currents interrupted by slackwater periods. Subfacies $4 a$ $(1538.2 \mathrm{~m})$.

$B$ : Intricately interwoven cross-lamination and undulating to even, parallel lamination generated by waves. Bioturbation is present. Subfacies $4 b(1521.0 \mathrm{~m})$.

An overall upward increasing clay content is seen in the heteroliths, and they are always overlain by claystones (facies 7). The upper boundaries of the heteroliths are placed arbitrarily where the clay or mud content increases to more than $50 \%$ and the clay-or mudstone layers become thicker than $5 \mathrm{~cm}$.

Bioturbation is intense in some horizons (fig. 11F) and the trace fossils Planolites, Diplocraterion, and Teichichnus, mentioned in decreasing abundance, are recognized.

Facies 5 makes up about $20 \%$ of the cored sequence in the Stenlille-1 well and $30 \%$ of that in the Lav $\varnothing-1$ well.

Interpretation: The heteroliths were deposited in a shallow marine environment as indicated by the presence of trace fossils from the Skolithos- and Cruziana ichnofacies (Seilacher 1967; Ekdale et al. 1984).
C: Graded sandstone bed interpreted as storm and waning storm deposit. The lower part consists of massive, medium-grained sandstone that grades into indistinctly crosslaminated, fine-grained sandstone. The topmost ripples are draped with mudstone laminae. Subfacies $4 c$ (1548.8 $m)$.

The occurrence of mudstone and only small-scale structured sandstone indicates that the depositional environment was characterized by relatively low energy. The sand and silt was mainly transported as bed load by wave and current induced processes, whereas the mudstone was deposited from suspension during calm water conditions. Mud laminae with thickness up to $2 \mathrm{~mm}$ can be deposited during a single slackwater period (Terwindt and Breusers 1982), while thicknesses up to 20-30 mm must be interpreted as sedimentation of mud laminae over several slackwater periods.

The thin upwards fining sequences reflect frequent shifts between periods with bedload transport of finegrained sand and periods with weak or no currents during which mud settled out. The main part of each sequence was probably deposited during one tidal period, as described from a mesotidal environment by Terwindt (1981). 


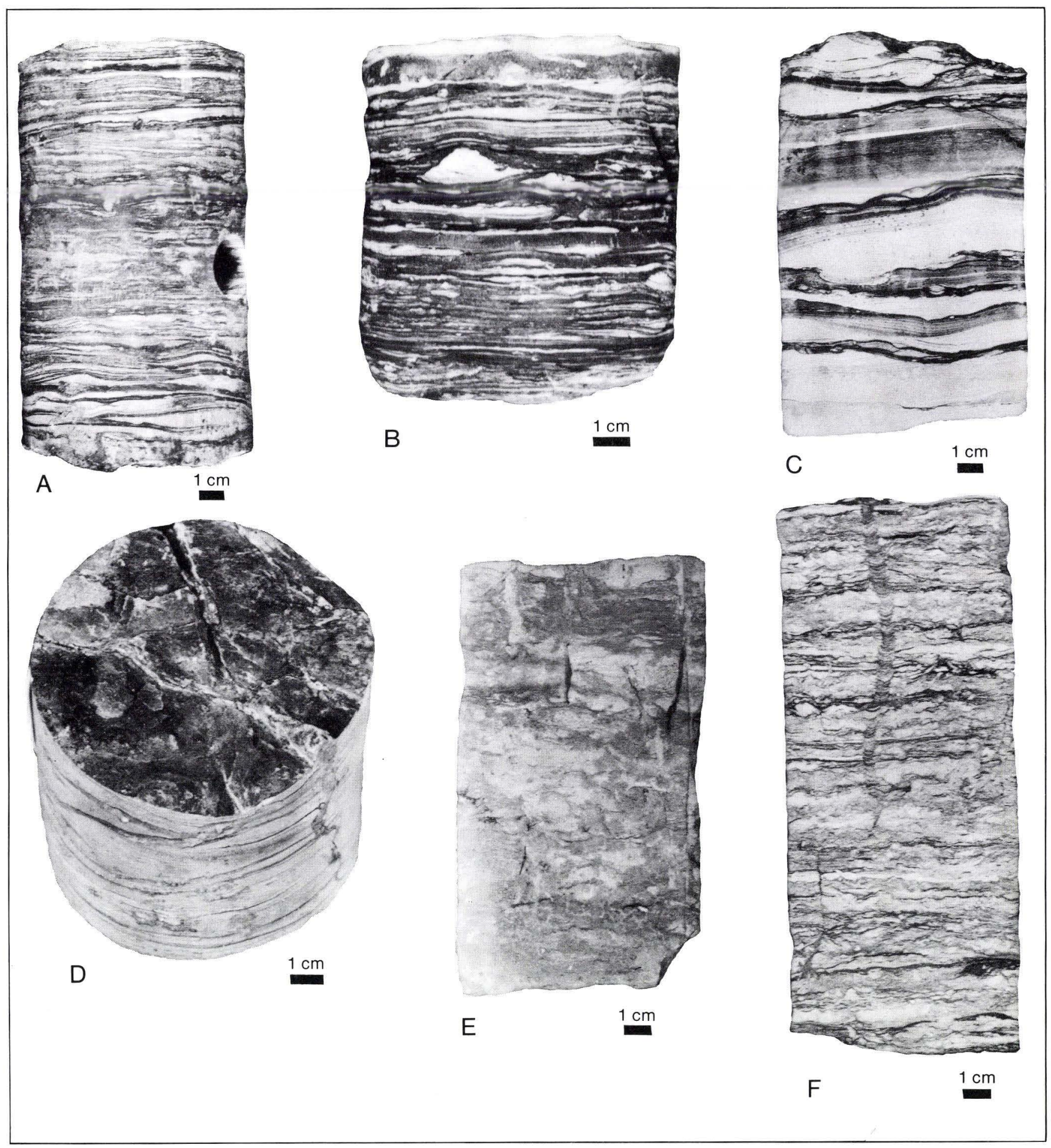

Fig. 11. Facies 5, heteroliths deposited on intertidal flats. A: Heterolith of fine-grained sandstone and dark mudstone characterized by lenticular and wavy bedding (Stenlille-1, 1543.9 $m$ ).

B: Heterolith of fine-grained sandstone and dark mudstone with lenticular bedding and parallel layered sandstone and mudstone (Lavø-1, $2164.9 \mathrm{~m}$ ). Sandstone lenses in this figure as well as in A are deformed due to compaction. Planolites occurs in both figures.

C: Thin graded sequences with sharp or erosive base. Cross-

Heteroliths with structures like facies 5 are commonly observed in subtidal and intertidal environments (Reineck 1960; Reineck and Wunderlich, 1968; Ter- lamination and parallel lamination characterize the finegrained sandstone in lower part of the sequences. The sandstones grade into thinly laminated siltstone and mudstone topped by relatively thick layers of dark mudstone or claystone (Stenlille-1, $1518.0 \mathrm{~m}$ ).

$D$ : Sand filled mudcracks indicative of subaerial exposure (Stenlille-1, $1541.3 \mathrm{~m}$ ).

E: Rootlets (Stenlille-1, $1544.3 \mathrm{~m}$ )

F: Bioturbated heterolith of facies 5 (Lavø-1, $2163.7 \mathrm{~m}$ ).

windt 1971; Terwindt and Breusers 1972; Reineck 1975; Reineck and Singh 1980). The large amount of sand filled mudcracks, interpreted as desiccation cracks de- 
veloped during subaerial exposure precludes a subtidal genesis and it is suggested that facies 5 were laid down on an intertidal mixed flat (Reineck 1975).

\section{Facies 6 - Small-scale cross- and parallel laminated siltstone}

Description: The major part of this facies consists of greyish-green, cross-laminated and parallel laminated siltstone. In most horizons these structures are masked by imprints from numerous rootlets (fig. 12A) and large plant fragments occur frequently. In some horizons the structures are disturbed by slumping, loading and water escape (fig. 12B).

A minor part of this facies consists of beds 1 to $8 \mathrm{~cm}$ thick consisting of small, platy, intraformational claystone clasts embedded in a clay- and siltstone matrix. The platy clasts are parallel to the bedding planes and an indistinct stratification is present. In most cases there seems to be a transitional contact between a bed consisting of clay clasts and the overlying siltstone, whereby small upward fining sequences are formed.

This facies is only seen in core 11 in the Lavø-1 well where it constitutes $95 \%$.

Interpretation: The cross-laminated siltstone was deposited by current ripples and the parallel laminated siltstone from suspension fall-out. The water depth was probably very shallow as indicated by the rootlets.

The few thin clay clast beds are evidence of brief erosional episodes followed by rapid sedimentation of silt, as indicated by the water escape structures. The numerous rootlets, the large plant fragments, the lack of bioturbation and marine microfossils suggest a vegetated non-marine environment.

\section{Facies 7 - Parallel laminated claystone}

Description: This facies consists of parallel laminated claystone with plant fragments. Especially in core 11 from the Lavø-1 well, large stems of Equisetites are very numerous (K. Raunsgaard Pedersen, pers. comm. 1986). Occasionally thin intercalations of siltstone and very fine-grained sandstone occur showing pinch and swell and incipient lenses.

Biogenic structures are sparse in the Stenlille- 1 well apart from Planolites burrows and a single questionable Thallasinoides burrow. No burrows are seen in core 11 in the Lavø-1 well.

This facies constitutes about $2 \%$ of the cored interval in Stenlille-1, and in the Lavø-1 well it constitutes about $5 \%$ of the cores.

Interpretation: The fine grain size and the parallel lamination show that deposition occurred in a calm environment, dominated by suspension fall-out. The occurrence of sand and siitstone laminae with poorly developed traction current structures show that the depositional site was periodically supplied with sand and silt, mainly settling out from suspension.

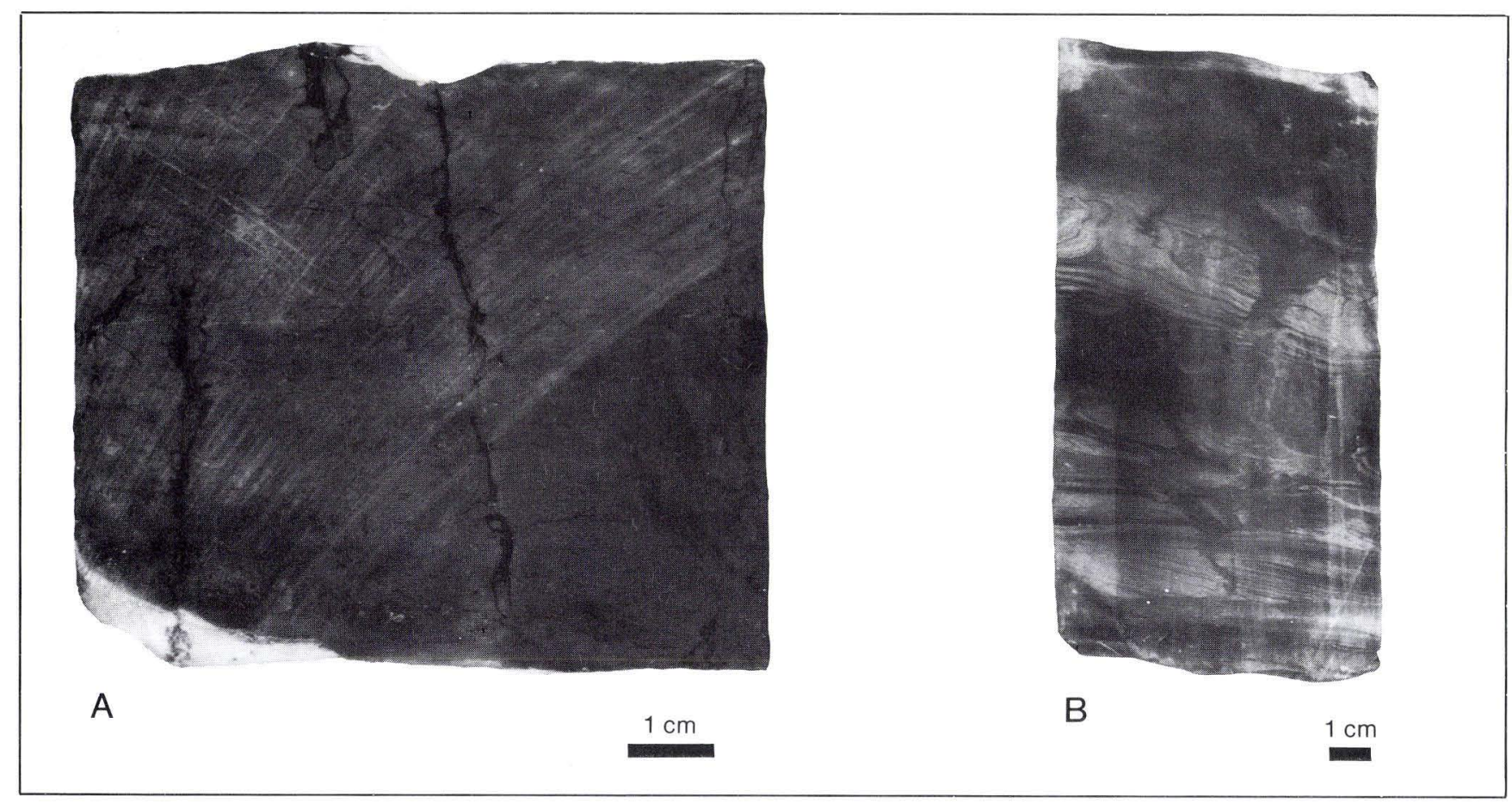

Fig. 12. Facies 6, siltstone deposited on a flood plain, Lavф-1.

A: Faintly laminated siltstone with numerous rootlets (2164.4 $m)$.
B: Siltstone with water escape structures and load structures $(2165.1 \mathrm{~m})$. 
In core 11 from Lavø-1 the presence of numerous stems of Equisetites indicate a non marine environment.

\section{Facies 8-Coal}

Description: This facies, which only occurs in one horizon in the cored interval in the Stenlille- 1 well, is a 0.4 $m$ thick, very argillaceous coal bed. The coal has a transitional lower boundary to a claystone belonging to facies 7 and shows a decreasing silt and clay content upwards. Large plant fragments are present in the coal.

The facies makes up less than $1 \%$ of the cored interval in Stenlille-1, and is not found in the Lavø-1 cores.

Interpretation: The coal bed may be allochthonous as no roots are seen in the underlying mudstone. The plant fragments were deposited in a quiet ponded environment possibly in the vicinity of vegetated areas. 


\section{Vertical succession of facies in the cored intervals}

\section{Stenlille-1}

Based on wireline logs and lithological descriptions of cores, cutting samples and sidewall cores the formation has been subdivided into eight sequences (A-H, fig. 13) of which the upper five were cored (sequences D-H, fig. 3). Although the cored sequences display some similarities, differences are seen, and each sequence will be analysed below.

Sequence D: Sequence D (fig. 3), which is c. $29 \mathrm{~m}$ thick, is dominated in the lower part by cross-bedded, fine- to medium-grained sandstone (facies 1 ), indicating relatively strong currents during deposition. The suggestions of bi-directional flows and unsteadiness of flow velocities points to a tidal current regime and the mudstone couplets strongly favour a subtidal setting (Visser 1980). Accordingly the lowermost $9 \mathrm{~m}$ of Sequence $\mathrm{D}$ are interpreted as subtidal deposits, laid down on subtidal sand flats.

A gradual change upwards to cross-laminated sandstones (facies $4 \mathrm{a}$ and $4 \mathrm{c}$ ), with intercalations of thin heteroliths (facies 5) takes place at about $1560 \mathrm{~m}$. Records of slackwater are preserved as thin mudstone flasers and drapes, and an increasing degree of bioturbation is seen. These changes indicate a general reduction of current velocity during deposition of this interval.

At $1555 \mathrm{~m}$ a scoured surface is overlain by crossbedded sandstone and a longitudinally cross-bedded heterolith (facies 3), interpreted as the fill of a tidal creek. Above, fine grained sandstone with cross-lamination and mudstone flasers dominate (facies $4 \mathrm{a}$ and 4c) with thin, heterolithic intercalations (facies 5).

From about $1545 \mathrm{~m}$ to $1541 \mathrm{~m}$ bioturbated heteroliths dominate. Rootlets and several horizons with desiccation cracks indicate shallow water depths and episodic subaerial exposure. The depositional area was probably an intertidal mixed flat.

At $1541 \mathrm{~m}$ the heteroliths gradually pass up into laminated claystone (facies 7), terminating Sequence D. This change may reflect transition from an intertidal mixed flat to a mud flat.

The sediments of Sequence D thus indicate a gradual transition from a subtidal sand flat with migrating megaripples into an intertidal sand flat with small ripples, passing into mixed flat where sandstone-mudstone heteroliths were deposited. The heteroliths grade up into claystone deposited on an intertidal mud flat.
Sequence D seems, therefore, to represent a progradation of the various types of tidal flats (Reineck 1975).

Sequence E: This sequence is $8 \mathrm{~m}$ thick (fig. 3 ) and is separated from Sequence D by a distinct erosion surface. This surface is overlain by fine-grained sandstone dominated by cross-lamination, flaser bedding and thin mudstone laminae (subfacies 4a) indicating a return to deposition from currents of sufficient strength to produce small ripples. Mud that settled out during slack water is preserved as flasers and thin laminae. Horizons with desiccation cracks indicate subaerial exposure. The sandstones were most likely deposited on intertidal sand flats.

At $1538 \mathrm{~m}$ a distinct erosional surface is overlain by a lag of large mudstone intraclasts. Above this surface several sets of fine-grained sandstone with low angle cross-bedding (facies 2) are present. This succession of beds is interpreted as parts of small washover fans that invaded the intertidal environment during storm events. The lithology beneath the cored interval (see later) may suggest the presence of barrier islands whereas indirect evidence is provided by the presence of tidal flat deposits, as tidal flats are dependent on protection from the open sea.

Above the washover fan deposits, Sequence $E$ is terminated by a heterolith (facies 5) passing into laminated, silty claystone (facies 7 ), probably representing the transition from intertidal mixed flat to mud flat.

Sequence F: This sequence is c. $8.5 \mathrm{~m}$ thick (fig. 3) and has a very sharp, erosional boundary upon Sequence E. It is dominated by creek fill sediments (facies 3 ). The creek fills display rather small thickness variations, from $0.6 \mathrm{~m}$ to $1.1 \mathrm{~m}$. In three cases the creek fills are overlain by assumed intertidal mixed flat heteroliths, and it is thus likely that the major part of the creek fill is preserved. Without correction for compaction the creek depths are in the range of $0.75 \mathrm{~m}$ to 1.00 $\mathrm{m}$.

The uppermost creek fill is overlain by mixed flat sediments passing up into mud flat sediments with coal which probably represents a marsh deposit.

Sequence $F$, therefore, reflects the progradation of tidal flats dissected by channels.

Sequence G: Sequence $\mathrm{G}$ is app. $10.5 \mathrm{~m}$ thick (fig. 3) and is separated from the coal bed capping Sequence $F$ 


\section{STENLILLE -1}

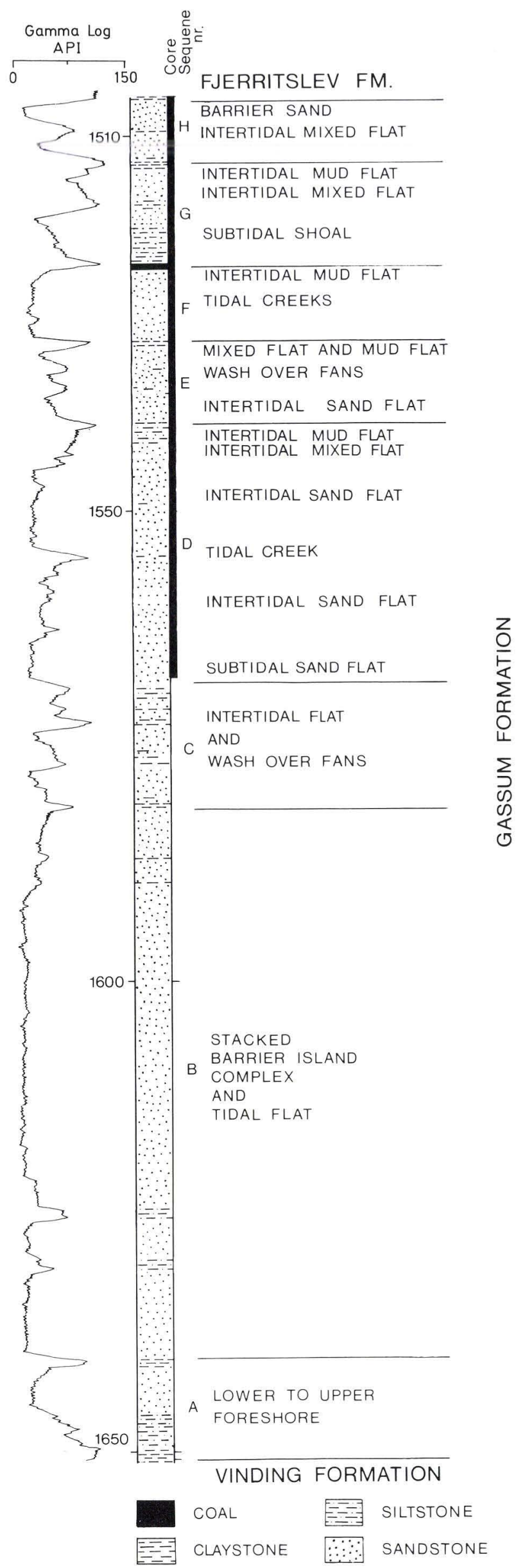

by an erosion surface. Although wave generated structures occur locally in the other sequences, the lower half of Sequence $G$ is the only interval where waverippled and bioturbated siltstones (facies $4 b$ ) dominate. Subordinate, thin, storm generated, sandy beds (facies $4 \mathrm{c}$ ) and current ripple laminated beds (facies 4a) are present. The clay content is low and the content of organic debris is considerably lower than elsewhere in the cores, probably due to winnowing by waves or greater distances to vegetated areas and river mouths. Mudstone flasers and laminae are evidence of periods with very limited water movement. A subtidal shoal exposed to waves is proposed as a possibility.

The middle part of Sequence $G$ is dominated by heteroliths with well developed, thin micro-sequences (facies 5) similar to those described from recent tidal flats (Terwindt 1981). These sequences and the occurrence of numerous desiccation cracks, point to intertidal mixed flat sedimentation.

The heteroliths pass up into laminated, silty claystone (facies 7), deposited on an intertidal mud flat. According to these suggestions, Sequence $G$ represents subtidal shoal deposits overlain by prograding tidal flat deposits.

Sequence $H$ : This sequence which is c. $6 \mathrm{~m}$ thick (fig. 3 ) shows a general upward coarsening trend.

The erosion surface which separates Sequence $G$ and $\mathrm{H}$ is overlain by inclined, thin and graded layers of siltstone and fine-grained sandstone (fig. 3). The upward decreasing dip of these layers (fig. 14), indicate a gradual infilling of a small pool. Upon these sediments follow presumed washover fan deposits and typical mixed flat heteroliths with desiccation cracks (facies 5).

The formation is terminated by a well to moderately sorted, fine- to medium-grained sandstone. Structures are difficult to identify, but a faint parallel lamination probably of upper flow regime origin appears to dominate. Above this sandstone bed, a thin heterolith with an erosive base marks the transition to the marine mudstone of the transgressive Fjerritslev Formation, described recently from this well by Pedersen (1985). The sparse data permit only a speculative interpretation of the uppermost two meters. However, the lithology and the position between inshore intertidal flat sediments and open marine mudstones favours a barrier island or an upper foreshore interpretation. Thus the upper part of sequence $\mathrm{H}$ probably represents a transgressive sequence.

Fig. 13. Gamma ray log and lithologies of the Gassum Formation in Stenlille-1. The positions and interpretations of sequences $A$ through $H$ are indicated. 


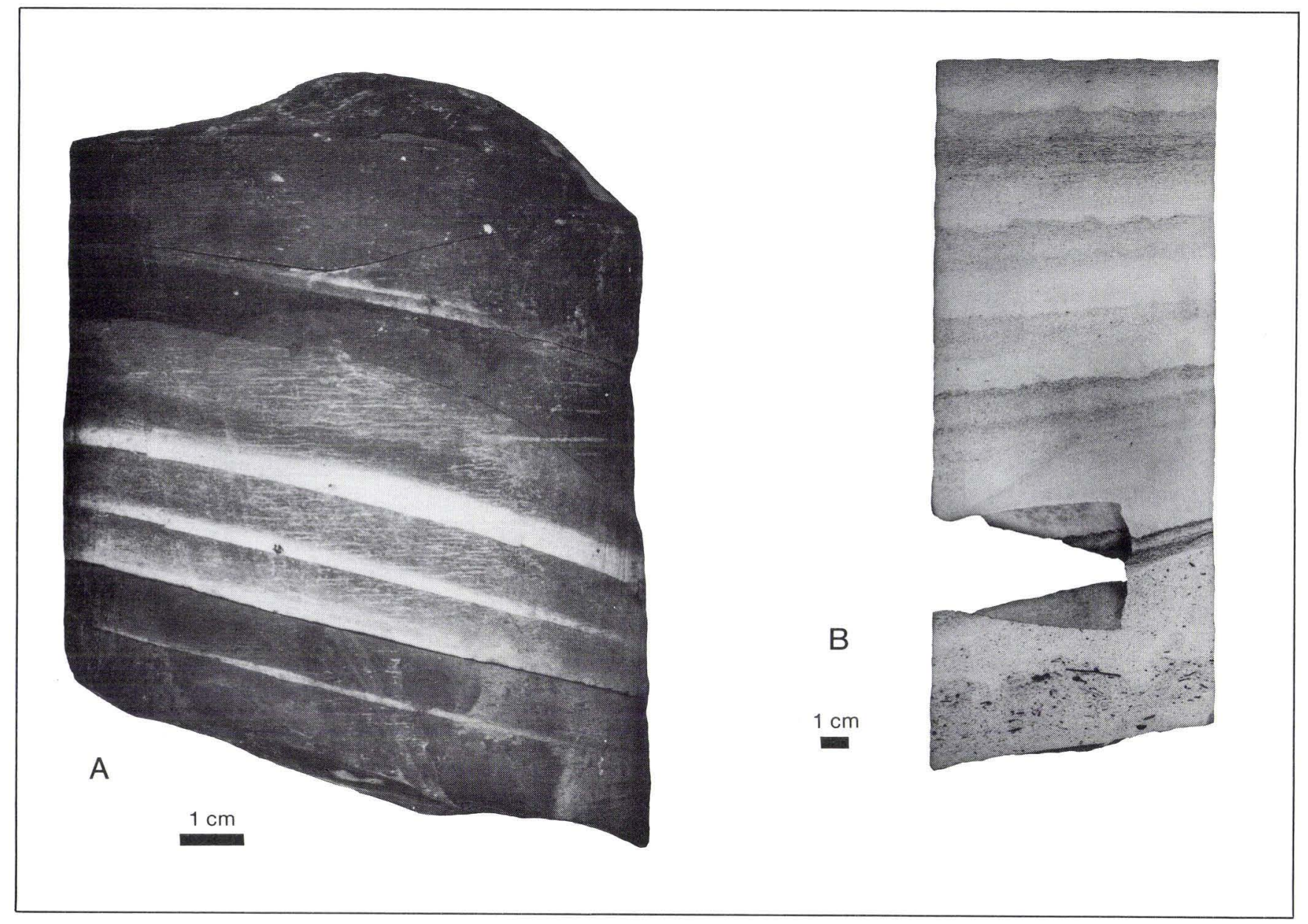

Fig. 14. Infill of a small pool or scour, Stenlille-1.

A: Inclined, graded layers of very fine-grained sandstone and silty claystone deposited by sediment clouds or slurries entering a body of stagnant water $(1512,7 \mathrm{~m})$.

$B$ : Inclined layers of fine-grained sandstone grading upward into very fine-grained sandstone with abundant small clay

\section{Lav $\varnothing-1$}

In the Lav $\varnothing-1$ well the length of the cores is very limited and it is not possible to define any general trends in the sediments.

Core 11 (figs. 2 and 4) consists of cross-laminated and parallel laminated siltstone with numerous rootlets (facies 6), and minor claystone beds with stems of Equisetites (facies 7). No marine indication is found and the Equisetites stems suggest a continental environment. The few thin layers of intraformational claystone clasts record minor erosional episodes, and core flakes and organic debris. The bases of the sandstone layers are loaded in places. In the lowermost layer the clay flakes are slightly imbricated and a tendency towards inverse to normal grading is seen indicating deposition from a heavily loaded sediment flow $(1511,8 \mathrm{~m})$.

11 may represent deposits that accumulated by overbank flooding on a flood plain.

In core 10 (fig. 4) heteroliths with wavy bedding (facies 5) dominate. The bioturbation is rather intense and masks the sedimentary structures. Diplocraterion, Zoophycos and Planolites can be identified. Desiccation cracks are seen at one level. The facies present are comparable with the fine-grained, heterolithic sediments in Stenlille-1. The trace fossils indicate a marine environment and as there is evidence in the cores of shallow water depth, an intertidal mixed flat is the most likely depositional environment. 


\section{Description and interpretation of the uncored parts of the formation}

The lithologies of the uncored parts of the formation in the three wells studied are known from wireline logs, cuttings samples and sidewall cores. Interpretation of the sedimentary environment in the uncored intervals can be made by referring to log motifs in the cored intervals where the depositional environments can be more safely interpreted.

\section{Stenlille-1}

Sequence A-C covers the uncored interval (1651.00$1568.40 \mathrm{~m}$, fig. 13). These sequences will be described and interpreted in the following section.

Sequence $A$ : This $10 \mathrm{~m}$ thick sequence (fig. 13) consists of fine- to medium-grained sandstone interbedded with siltstone (Christensen, 1981). The sequence overlies brackish-marine mudstone of the Vinding Formation. In combination with the interpretation of the upper part of the Gassum Formation presented above this leads to the assumption that the lower part was deposited in a shallow marine, regressive environment. It is suggested that the relatively coarse-grained sediments with fine-grained intercalations were deposited on a lower to upper shoreface.

Sequence $B$ : This sequence is nearly $58 \mathrm{~m}$ thick and is dominated by moderately to well sorted, medium- to coarse-grained sandstone (Christensen, 1981). The gamma ray log motif shows a clean sandstone with few fine-grained intercalations (fig. 13). Palynological investigations show a mixing of marine and land derived kerogen (Hansen, 1981). The general geological setting and the presence of wave protected intertidal flat sediments and washover sand bodies in the cored part of the formation suggest that such a sequence of thick, clean, medium- and coarse-grained sandstone was deposited in a coastal barrier environment.

Sequence $C$ : Sequence $C$ is app. $14.5 \mathrm{~m}$ thick and is characterized by claystone and siltstone with at least three major intercalations of fine-grained sandstone. The gamma ray log (fig. 13) shows that deposition took place as three claystone-sandstone cycles.

As no further sedimentologic evidence is available from sequence $C$ the interpretation is rather tentative. The fine-grained sediments of the sequence reflect low depositional energy and may be the deposits of an intertidal flat. The sandstones are evidence of intermittent higher energy and may be interpreted as washover fans.

\section{Lav $\varnothing-1$}

The lithology of the uncored parts of the Gassum Formation in the Lavø-1 well, as estimated from cuttings samples and electric logs, is dominated by light grey to green, fine-grained sandstone and dark grey claystone with few thin layers of coal (Dinesen 1960). The lithology of the cored intervals generally confirms this observation, but core 10 indicates that sand and clay in some horizons were deposited as heteroliths.

The log motif of the SP log indicates frequent changes of lithology, but generally the lower one-third is dominated by siltstones and sandstones, whereas the upper two thirds apart from the topmost $10 \mathrm{~m}$ thick sandstone layer are dominated by claystones and heteroliths with thin sandstone horizons (fig. 2).

Marine microfossils seem to be absent in the lower part of the formation apart from a sparse ostracod fauna found in cuttings from the interval, 2301-2304 m (Michelsen 1975). As the sediments in core 11 (fig. 2 and fig. 4) are interpreted as floodplain deposits in the previous section, a marginal marine to floodplain environment is tentatively suggested for the lower part of the formation in the area of the Lav $\varnothing-1$ well.

For the upper part of the formation a marine to brackish origin is inferred due to the proposed tidal flat origin of the sediments in core 10 , a sparse ostracod fauna in the interval 2210-2213 (Michelsen 1975) and the finds of foraminifera (Dentalina matutina (?) and Marqinulina prima, I. Bang written communication, 1986) in cuttings from the sandstone interval topmost in the formation. This presumed transgressive sand sheet topmost seems to be of Late Sinemurian or Early Pliensbachian age (Michelsen, 1975).

\section{Slagelse-1}

No cores were taken in the Gassum Formation in Slagelse-1, but cuttings samples and wireline log motifs show that the formation is characterized by dark grey claystones with thin siltstone beds and lignite fragments 
(Larsen and Buch 1960, Sorgenfrei and Buch 1964). It seems that the deposition took place in a quiet marine environment (Larsen 1966). The dominant claystones point to deposition on an inner shelf rather than at inshore tidal areas as in Stenlille-1. In other wells lo- cated centrally or southerly in the basin, e.g. Vinding-1, Nøvling-1, Rønde-1 and Horsens-1 (fig. 1), the Gassum Formation is also dominated by marine claystones and siltstones (Sorgenfrei and Buch 1964; Larsen 1966; Rasmussen 1971, 1973). 


\section{Depositional model and palaeogeography}

The above interpretation of cores and petrophysical logs in the Lavø-1, Stenlille-1 and Slagelse-1 wells have shown that the Gassum Formation on Sjælland was deposited in a shallow marine to fluvial environment. An isopach map of the formation indicates that the general trend of the palaeo-coast was northwest-southeast during deposition of the formation in Late Triassic - Early Jurassic times (Bertelsen 1978, fig.7).

In the Slagelse-1 well, located farthest to the southwest and thus farthest out into the basin, the formation mainly consists of marine claystone with thin silty intervals. In the nearby Stenlille-1 well (fig. 1) the formation consists of stacked barrier island deposits overlain by four regressive tidal flat sequences, capped by a transgressive sequence marking the transition to the overlying marine claystones. In these two wells the Gassum Formation has a Rhaetian age.

In the Lav $\varnothing-1$ well, located farthest to the northeast at the basin margin, a marginal marine to flood plain environment is suggested for the lower part of the formation. This part of the formation is probably laterally equivalent to the sections in the Slagelse- 1 and Stenlille-1 wells. For the upper part of the formation in the Lav $\varnothing-1$ well a marine to brackish environment is inferred and the age determinations (Michelsen 1975) suggest that this part of the formation is laterally equivalent to the fully marine claystone of the Fjerritslev Formation farther out in the basin as seen at Stenlille-1 and Slagelse-1.

In Stenlille-1 a number of tidal subenvironments have been identified, and their vertical distribution reflects a series of regressions and transgressions. Three major intervals are recognized:

The first interval comprises Sequence A (fig. 13), which is interpreted to represent deposition on the lower to upper shoreface on the seaward side of a coastal barrier as the result of progradation of the shoreline; this event may reflect the eustatic fall in sea-level in the Early Rhaetian proposed by Hallam (1981, 1984).

The second interval comprises Sequence B-G, re- flecting a period with relatively stable sea-level. These sediments were deposited on barrier islands and on subtidal and intertidal flats, mainly in the landward portions of the tidal environment. Washover fans present in the cored tidal flat deposits indicate that a barrier island may have been situated near the well location during the deposition of these sediments. The regional paleogeography suggests that the barrier was situated to the west or southwest of the Stenlille area.

Sequence $H$ constitutes the third major interval. Its transgressive character reflects a sea-level rise leading to the deposition of the fully marine Fjerritslev Formation. It can be regarded as local evidence of the Early Jurassic, eustatic sea-level rise (Michelsen 1975, 1978; Bertelsen 1978; Pedersen 1983; Hallam 1984).

The palaeotidal range may be estimated by analogy to recent tidal environments (Klein 1971). In mesotidal settings the deposits are dominated by small-scale sedimentary structures (Reineck 1975), whereas in macrotidal settings, the anticipated sequences are dominated by large-scale structures or by plane beds (Dalrymple et al. 1985). Washover deposits are best developed in micro- to mesotidal environments (Schwartz 1982; Hayes 1975, 1979).

These general lines of evidence and the fact that the thicknesses of the channel fill deposits in the cored intervals never exceed $1.1 \mathrm{~m}$, point to a micro- to mesotidal regime during deposition of the Gassum Formation. The tidal deposits of the Early Jurassic Helsingborg Member in Skåne, southern Sweden, and the Galgeløkke Member on Bornholm were also deposited in a micro- to mesotidal environment (Sellwood 1972, 1975; Frandsen 1977; Rolle et al. 1979; Gravesen et al. 1982).

In conclusion, the identification herein of a range of tidal subenvironments, together with the general upward fining trend of the formation, suggests that the earlier deltaic depositional model (Larsen 1966; Bertelsen 1978, 1980) for the Gassum Formation is not valid for the southeastern part of the Danish Subbasin. 


\section{Acknowledgements}

Gunver Krarup Pedersen is thanked for critically reading an early version of the paper and for helpful suggestions. Further, the paper benefited from a critical review by Finn Surlyk and Olaf Michelsen. Jon Ineson proposed valuable changes and improved the English language. We thank Olaf Michelsen, Inger Bang and Kaj Raunsgaard Pedersen for the identification of fos- sils cited in the text. We had fruitful discussion with Lise Holm and Peter N. Johannessen. Carlos and Irma Torres made the photographs, Inge Martin-Legéne, and Eva Melskens did the drawing, Pia Andersen, Dorthe Plougmann, and Heinke Andersen did the typing. All are thanked for their contributions. 


\section{References}

Barwis, J.H. and Hayes, M.O., 1985. Antidunes on modern and ancient washover fans. Journal of Sedimentary Petrology, Vol. 55, No. 6, pp. 907-916.

Bertelsen, F., 1978. The Upper Triassic - Lower Jurassic Vinding and Gassum Formations of the Norwegian-Danish Basin. Geological Survey of Denmark. Series B, No. 3, 25 p.

Bertelsen, F., 1980. Lithostratigraphy and depositional history of the Danish Triassic. Geological Survey of Denmark. Series B, No. 4, $59 \mathrm{p.}$

Bridges, P.H. and Leeder, M.R., 1976. Sedimentary model for intertidal mudflat channels with examples from the Solway Firth, Scotland. Sedimentology, Vol. 23, pp. 533-552.

Carter, C.H., 1975. Miocene-Pliocene Beach and Tidal Deposits, Southern New Jersey. In: Ginsburg, Robert N. (ed.): Tidal Deposits: A Casebook of Recent Examples and Fossil Counterparts, Springer Verlag, Berlin, pp. 109-117.

Christensen, 0.B., 1971. Biostratigraphical investigation of the Triassic in Rønde No. 1 and the Triassic-Jurassic boundary. In: Rasmussen, L. Banke (ed.): Dybdeboringen Rønde nr. 1 på Djursland Geological Survey of Denmark. III. Series No. 39, pp 92-93.

Christensen, 0.B., 1973. The Vinding Formation (Upper Triassic) in Nøvling No. 1. In: Rasmussen, L. Banke (ed.): Dybdeboringen Nøvling nr. 1 i Midtjylland. Geological Survey of Denmark. III. Series No. 40, pp. 132-135.

Christensen, 0.W., 1981. Stenlille no. 1, Geological well completion report, 91 p., DGU Well File No. 205.514. Geological Survey of Denmark.

Clifton, H.E., 1976. Wave-Formed Sedimentary Structures - a conceptual model. In: Beach and Nearshore Sedimentation (Ed. by R.A. Davis Jr. and R.L. Ethington), pp. 126-148. Spec. Publ. Soc. econ. Paleont. Miner., 24, Tulsa.

Clifton, H.E., Hunter, R.E. and Phillips, R.L., 1971. Depositional structures and processes in the non-barred high energy nearshore. Journal of Sedimentary Petrology, Vol. 41, pp. 651-670.

Dalrymple, R.W., Knight, R.J. and Middleton, G.V., 1985. Facies distribution and sequences in a macrotidal estuary, Cobequid BaySalmon River Estuary, Bay of Fundy, Canada. Symposium on Modern and Ancient Clastic Tidal Deposits, University of Utrecht, The Netherlands, 26.-28. August. Abstracts.

Davidson-Arnott, R.G.D. and Greenwood, B., 1976. Facies Relationships on a Barred Coast, Kouchibouguac Bay, New Brunswick, Canada. In: Beach and Nearshore Sedimentation (Ed. by R.A. Davis Jr. and R.L. Ethington). Spec. Publ. Soc. econ. Paleont. Miner., 24, Tulsa.

de Mowbray, T., 1983. The genesis of lateral accretion in recent intertidal mudflats channels, Solway Firth, Scotland. Sedimentology 30 p. $425-435$.

de Raaf, J.F.M., Boersma, J.R. and van Gelder, A., 1977. Wavegenerated structures and sequences from a shallow marine succession, Lower Carboniferous, County Cork, Ireland. Sedimentology, Vol. 24, pp. 451-483.

Dinesen, A., 1960. Rapport over Lavø nr. 1. Geological Survey of Denmark. File No. 186.165, 22 p.

Ekdale, A.A., Bromley, R.G., and Pemberton, S.G., 1984. Ichnology - Trace Fossils in sedimentology and Stratigraphy. SEPM short course No.15, $316 \mathrm{p}$.

Frandsen, N., 1977. Aflejringsmiljøer i Skånes Rhæt-Lias. Unpublished thesis. University of Copenhagen, $150 \mathrm{p}$.

Gravesen, P., Rolle, F., and Surlyk, F., 1982. Lithostratigraphy and sedimentary evolution of the Triassic, Jurassic and Lower Cretaceous of Bornholm, Denmark. Geological Survey of Denmark, Series B, No. 7, $51 \mathrm{p}$.

Gry, H., 1969. Megaspores from the Jurassic of the Island of Bornholm. Denmark. Bull. Geol.Soc. of Denmark, Vol. 19, pp. 69-89.
Hallam, A., 1981. A revised sea-level curve for the early Jurassic. Journal of Geol. Soc., Vol. 138, pp. 735-743.

Hallam, A., 1984. Pre-Quaternary Sea-Level Changes. Ann. Rev. Earth Planet. Sci., Vol. 12, pp. 205-243.

Hansen, J.M., 1981. In: Christensen, 0.W: Stenlille no. 1. Geological well completion report, pp. 81-87. DGU well File No. 205-514. Geological Survey of Denmark.

Harms, J.C., Southard, J.B. and Walker, R.G., 1982. Structures and sequences in clastic rocks. SEPM short course No. 9, Calgary.

Hayes, M.0., 1975. Morphology of sand accumulations in estuaries. In: Cronin, L.E. (ed.): Estuarine Research, Vol. 2. Geology and Engineering. New York. Academic Press, pp. 3-22.

Hayes, M.0., 1979. Barrier - island morphology as a function of tidal and wave regime. In: Leatherman, S.P. (ed.). Barrier Islands From the Gulf of St. Lawrence to the Gulf of Mexico. New York. Academic Press, pp. 1-28.

Jopling, A.V., 1965. Hydraulic factors and the shape of laminae. Journal of Sedimentary Petrology. Vol. 35, pp. 777-791.

Klein, G., de Vries, 1971. A sedimentary model for determining paleotidal range. Geol. Soc. Am. Bull. 82, pp. 2585-2592.

Larsen, G., 1966. Rhaetic - Jurassic - Lower Cretaceous Sediments in the Danish Embayment. (A Heavy - Mineral Study). Danm. geol. Unders., II. Rk, No. 91, 127 p.

Larsen, G. and Buch, A., 1960. Dybdeboringen Slagelse nr. 1. In: Medd. fra Dansk Geologisk Forening. Copenhagen, Vol. 14. p. 281

Michelsen, 0., 1975. Lower Jurassic biostratigraphy and ostracods of the Danish Embayment. Geological Survey of Denmark. Series III, No. 104, 287 p.

Michelsen, 0., 1978. Stratigraphy and distribution of Jurassic deposits of the Norwegian-Danish Basin. Geological Survey of Denmark. Series B, No. 2, $34 \mathrm{p}$

Michelsen, 0., 1980. Jurassic of the Stenlille no. 1 Well. Internal note. Geological Survey of Denmark.

Norling, E. and Bergström, J., 1987. Mesozoic and Cenozoic tectonic evolution of Scania, southern Sweden. In: P.A. Ziegler (Ed.), Compressional Intra-Plate Deformations in the Alpine Foreland. Tectonophysics, 137: 7-19.

Pedersen, G.K., 1983. En sedimentologisk unders $\emptyset$ gelse af den Nedre Jurassiske Fjerritslev Formation i det Danske Subbassin. Geological Survey of Denmark/Thesis study, University of Copenhagen. $43 \mathrm{p}$.

Pedersen, G.K., 1985. Thin, fine-grained storm layers in a muddy shelf sequence: an example from the Lower Jurassic in the Stenlille-1 well. J. Geol. Soc. London. Vol. 142, pp.357-374.

Pegrum, R.M., 1984. Structural development of the southwestern margin of the Russian - Fennoscandian Platform. In: Petroleum geology of the North European Margin. Norwegian Petroleum Society. Graham and Trotman. pp. 359-369.

Poulsen, N., 1985. Rhaetian dinocysts in a core sample of the Lavø 1 well, Denmark. Internal Note. Geological Survey of Denmark.

Rasmussen, L. Banke (ed.), 1971. Dybdeboringen Rønde nr. 1 på Djursland. Geological Survey of Denmark. III. Series No. 39, 123 p.

Rasmussen, L. Banke (ed.), 1973. Dybdeboringen Nøvling nr. 1 i Midtjylland. Geological Survey of Denmark. III. Series No. 40, $164 \mathrm{p}$.

Reineck, H.E., 1958. Longitudinale Schrāgschichten im Watt. Geol. Rundschau, Vol. 47, pp. 73-82.

Reineck, H.E., 1960. Uber die Entstehung von Linsen - und Flaserschichten. Abhandl. Deut. Akad. Wiss., Vol. 1, pp. 370-374.

Reineck, H.E., 1967. Layered sediments of Tidal Flats, Beaches, and Shelf Bottoms of the North Sea. Amer. Assoc. Adv. Sci. Publ., 83, pp. 191-206. 
Reineck, H.E., 1972. Tidal Flats. In: Rigby, D.K. and Hamblin, W.K. (eds.): Recognition of ancient sedimentary environments. SEPM Spec. Publ. No. 16, pp. 146-159.

Reineck, H.E., 1975. German North Sea Tidal Flats. In: Ginsburg, Robert N. (ed.): Tidal Deposits. A casebook of Recent Examples and Fossil Counterparts. Springer Verlag, pp. 5-20.

Reineck, H.E. and Singh, J.D., 1980. Depositional Sedimentary Environments. Springer Verlag. 542 p.

Reineck, H.E. and Wunderlich, F, 1968. Classification and Origin of Flaser and Lenticular Bedding. Sedimentology, Vol. 11, pp. 99104.

Rolle, F., Koch, J.0., Frandsen, N. and Surlyk, F., 1979. Jurassic Environments in the Fennoscandian Border Zone. Symposium "Sédimentation jurassique W. européen«. Association des Sédimentologistes Francais, Publication spéciale, No. I, pp. 15-31.

Schwartz, R.K., 1982. Bedform and stratification characteristics of some modern small-scale washover sand bodies. Sedimentology, Vol. 29, pp. 835-849.

Seilacher, A., 1967. Bathymetry of Trace Fossils. Marine Geology, Vol. 5, pp. $413-428$.

Sellwood, B.W., 1972. Tidal-Flat Sedimentation in the Lower Jurassic of Bornholm, Denmark. Palaeogeogr. Palaeoclimatol., Palaeoecol., Vol. 11, pp. 93-106.

Sellwood, B.W., 1975. Lower Jurassic Tidal-Flat Deposits Bornholm, Denmark. In: Ginsburg, Robert N. (ed.): Tidal Deposits. A Casebook of Recent Examples and Fossil Counterparts. Springer Verlag, pp. 93-103.

Sivhed, U., 1984. Litho- and Biostratigraphy of the Upper Triassic Middle Jurassic in Scania, Southern Sweden. Geological Survey of Sweden. Yearbook, 78, no. 4, 31 p.

Smith, D.G., 1985. Modern mesotidal - influenced meandering river pointbar deposits: Examples similar to the Athabasca Oil Sands in the McMurray Formation, Northeast Alberta, Canada. Symposium on Modern and Ancient Clastic Tidal Deposits, University of Utrecht, The Netherlands, 26-28 August. Abstracts.
Smith, D.G., 1988: Modern point bar deposits analogous to the Athabarca Oil Sands, Alberta, Canada. In: de Boer, P.L., van Gelder, A. and Nio, S.D. (eds.): Tide-influenced Sedimentary Environments and Facies. D. Reidel Publishing Company, pp. $417-432$

Sorgenfrei, T. and Buch, A., 1964. Deep tests in Denmark 19351959. Geological Survey of Denmark, III. Series, No. 36, 146 p.

Terwindt, J.H.J., 1981. Origin and sequences of sedimentary structures in inshore mesotidal deposits of the North Sea. Spec. Publ. Int. Ass. Sediment. Vol. 5, pp. 4-26.

Terwindt, J.H.J. and Breusers, H.N.C., 1972. Experiments on the Origin of Flaser, Lenticular and Sand-Clay Alternating Bedding. Sedimentology, Vol. 19, pp. 85-98.

Terwindt, J.H.J. and Breusers, H.N.C., 1982. Flume experiments on the origin of flaser bedding. Sedimentology, Vol. 29, pp. 903-907.

Troedsson, G.T., 1932. Några tektoniska och stratigrafiska problem $i$ Skåne. Geol. Fören. Förhandl., Vol. 54, pp.

Vail, P.R. and Todd, R.G., 1981. Northern North Sea Jurassic Unconformities, Chronostratigraphy and Sea-level Changes from Seismic Stratigraphy. In: »Petroleum Geology of the Continental Shelf of North West Europe«, pp. 216-235.

van Straaten, L.J.J.U., 1954. Composition and Structure of recent marine sediments in the Netherlands. Leidse geol. Med., Vol. 19, pp. 1-110.

Vejbæk, 0.V., 1985. Seismic Stratigraphy and Tectonics of Sedimentary Basins around Bornholm, Southern Baltic. Geological Survey of Denmark. Series A, No. 8. 30 p.

Visser, M.J., 1980. Neap - spring cycles reflected in Holocene subtidal large-scale bedform deposits: A preliminary note. Geology, Vol. 8, pp. 543-546.

Zaitlin, B.A. and Dalrymple, R.W., 1985. Depositional patterns and stratigraphic sequences from the inner part of a sand-dominated, macrotical estuary, Cobequid Bay-Salmon River estuary, Bay of Fundy. Symposium on Modern and Ancient Clastic Tidal Deposits, University of Utrecht, The Netherlands, 26-28 August. Abstracts. 
This paper presents an interpretation of the depositional environment of the Upper Triassic - Lower Jurassic Gassum Formation on Sjalland. The work is carried out on information from conventional cores and wire-line logs from three released wells. The principal part is based on data from the Stenlille-1 well. 